\title{
Hydrotreatment of Kraft Lignin to Alkylphenolics and Aromatics Using Ni, Mo, and W Phosphides Supported on Activated Carbon
}

\author{
Ramesh Kumar Chowdari, ${ }^{\dagger,+}$ Shilpa Agarwal, ${ }^{\dagger, \S}$ and Hero Jan Heeres* ${ }^{* \dagger}{ }^{\dagger}$ \\ ${ }^{\dagger}$ Chemical Engineering Department, ENTEG, Faculty of Mathematics and Natural Science, University of Groningen, Nijenborgh 4, \\ 9747 AG Groningen, The Netherlands \\ ${ }^{\ddagger}$ Centro de Nanociencias y Nanotecnologia, Universidad Nacional Autonoma de Mexico, Km. 107 Carretera Tijuana-Ensenada, \\ 22800 Ensenada, Baja California, Mexico \\ ${ }^{\S}$ Catalytic Processes and Materials, MESA+ Institute for Nanotechnology, Faculty of Science and Technology, University of Twente, \\ P.O. Box 217, 7500 AE Enschede, The Netherlands
}

\section{Supporting Information}

\begin{abstract}
The conversion of lignin to biofuels and biobased chemicals is currently attracting a lot of attention. We here report on the valorization of Kraft lignin by a catalytic hydrotreatment using $\mathrm{Ni}$, Mo, and $\mathrm{W}$ phosphide catalysts supported on activated carbon in the absence of an external solvent. Experiments were carried out in a batch setup in the temperature range of $400-500{ }^{\circ} \mathrm{C}$ and 100 bar initial $\mathrm{H}_{2}$ pressure. The synthesized catalysts were characterized by X-ray diffraction, nitrogen physisorption, and transmission electron microscopy. The lignin oils were analyzed extensively by different techniques such as GPC, GCMS-FID, ${ }^{13} \mathrm{C} \mathrm{NMR}$, and elemental analysis. Two-dimensional gas chromatography (GCXGC-FID) was applied to identify and quantify distinct groups of compounds (aromatics, alkylphenolics, alkanes, etc.). Mo-based catalysts displayed higher activity compared to the W-containing catalysts. The reaction parameters such as the effect of reaction temperature, reaction time, and catalyst

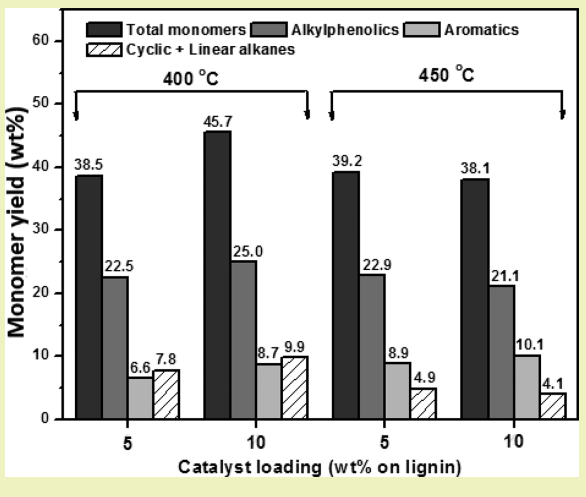
loading were studied for two catalysts (15MoP/AC and $20 \mathrm{NiMoP} / \mathrm{AC})$, and optimized reaction conditions regarding yields of monomeric components were identified $\left(400{ }^{\circ} \mathrm{C}, 100 \mathrm{bar} \mathrm{H}_{2}\right.$ at $\mathrm{RT}, 10$ wt $\%$ catalyst loading on lignin intake). The highest monomer yield (45.7 wt \% on lignin) was obtained for the $20 \mathrm{NiMoP} / \mathrm{AC}$ (Ni 5.6 wt \%, Mo 9.1 wt \%, P 5.9 wt \%) catalyst, which includes $25 \%$ alkylphenolics, $8.7 \%$ aromatics, and $9.9 \%$ alkanes. Our results clearly reveal that the phosphide catalysts are highly efficient catalyst to depolymerize the Kraft lignin to valuable biobased chemicals and outperform sulfided NiMo catalysts (monomer yield on lignin < $30 \mathrm{wt} \%$ ).
\end{abstract}

KEYWORDS: Kraft lignin, Hydrotreatment, Depolymerization, Phosphided catalysts, Biobased chemicals

\section{INTRODUCTION}

Lignin is one of the major components in lignocellulosic biomass and has great potential to be used as a feedstock for biofuels and biobased chemicals. ${ }^{1-4}$ It consist of a complex 3$\mathrm{D}$ structure with substituted aromatic rings linked by $\mathrm{C}-\mathrm{C}$ and $\mathrm{C}-\mathrm{O}$ bonds. $^{5-7}$ Cleavage of the linkages is in theory an attractive way to obtain low molecular weight aromatics and phenolics. ${ }^{8}$ However, its high structural heterogeneity and low reactivity of particularly the $\mathrm{C}-\mathrm{C}$ linkages combined with the typically harsh reaction conditions required to breakdown the polymer hamper effective depolymerization strategies.

Lignin can be obtained from lignocellulosic biomass by a range of processes. ${ }^{9-12}$ Kraft and lignosulfonates lignins are commercially produced by the pulp and paper industry. Due to the use of sulfur reagents in the process, sulfur $(1-2 \%)$ is incorporated in these lignin. ${ }^{13}$ About 55 million tons of such sulfur-containing lignins are produced annually, yet these are currently only used as an energy source in the paper mill. ${ }^{14}$ It is estimated that about $8-11 \mathrm{Mt} \cdot \mathrm{y}^{-1}$ of these lignins can be used to produce aromatic platform chemicals like phenols or aromatics (benzene, toluene, xylenes) without affecting the operation of the paper mills. ${ }^{15-17}$

Several methodologies have been explored for Kraft lignin depolymerization such as oxidation, ${ }^{18-20}$ reduction, ${ }^{21-24}$ and pyrolysis. ${ }^{25-27}$ Lignin depolymerization by reductive methods is generally carried out using hydrogen and a heterogeneous catalyst in the presence of an acid or base $\mathrm{e}^{23,28-30}$ and typically in a protic solvent such as methanol, ${ }^{31}$ ethanol, ${ }^{32-34}$ isopropanol, $^{35}$ and water (hydrothermal method). ${ }^{1,29,36-41}$ The catalytic reductive depolymerization with hydrogen (hydrotreatment) without an external solvent has been studied as well (Table 1). ${ }^{42-48}$ This does not imply the occurrence of solid-gas reactions only, as Kraft lignin is known to start to liquefy at relatively low temperatures $\left(175-200{ }^{\circ} \mathrm{C}\right)$ and as

Received: September 2, 2018

Revised: December 6, 2018

Published: December 17, 2018 
Table 1. Literature Data for the Catalytic Hydrotreatment of Various Lignins in the Absence of an External Solvent

\begin{tabular}{|c|c|c|c|c|c|c|c|}
\hline lignin & catalyst & $\begin{array}{l}\text { temp. } \\
\left({ }^{\circ} \mathrm{C}\right)\end{array}$ & $\mathrm{H}_{2} \underset{(\text { bar })}{\text { pressure }}$ & $\begin{array}{l}\text { time } \\
(\mathrm{h})\end{array}$ & $\begin{array}{l}\text { total yield of monomers } \\
(\%)^{a}\end{array}$ & $\begin{array}{l}\text { oil yield } \\
(\%)^{a}\end{array}$ & ref \\
\hline Organocell & $21 \% \mathrm{NiMo} / \mathrm{Al}_{2} \mathrm{SiO}_{5}$ & 420 & 100 & 1 & 21.8 & 61.6 & 42 \\
\hline Kraft & $\begin{array}{l}\mathrm{S}-21 \% \mathrm{NiMo} / \mathrm{Al}_{2} \mathrm{SiO}_{5}+\mathrm{S}-20 \% \mathrm{Cr}_{2} \mathrm{O}_{3} / \mathrm{Al}_{2} \mathrm{O}_{3} \\
(1: 1)\end{array}$ & 430 & 90 & 1 & 38.4 & 57 & 43 \\
\hline \multirow[t]{2}{*}{ pyrolytic lignin } & $\mathrm{Ru} / \mathrm{C}$ & 400 & $100^{d}$ & 4 & $39.8^{b}$ & 75.8 & 44 \\
\hline & & & & & $51.3^{c}$ & 75.4 & \\
\hline \multirow[t]{2}{*}{ Alcell } & $\mathrm{Ru} / \mathrm{C}$ & 400 & $100^{d}$ & 4 & 22.1 & 63.9 & 45 \\
\hline & & & & 8 & 29.7 & 72.8 & \\
\hline Kraft & $\mathrm{S}-\mathrm{NiMo} / \mathrm{MgO}-\mathrm{La}_{2} \mathrm{O}_{3}$ & 350 & $100^{d}$ & 4 & 26.4 & 48.2 & 46 \\
\hline Kraft & limonite & 450 & $100^{d}$ & 4 & 31 & 33.7 & 47 \\
\hline
\end{tabular}

${ }^{a}$ Yield is in wt $\%$ on lignin intake. ${ }^{b}$ Lignin from pine wood. ${ }^{c}$ Forestry residue. ${ }^{d}$ Initial pressure at room temperature, up to 200 bar at actual reaction temperature.

such acts as the (reactive) solvent at hydrotreatment reaction conditions. In addition, monomers (phenolics, aromatics, etc.) formed by thermal and catalytic reactions already at an early stage of the batch process will also act as the solvent. ${ }^{44}$ Typically, relatively harsh conditions are used with temperatures between 350 and $450{ }^{\circ} \mathrm{C}$ and initial hydrogen pressures at room temperature up to 100 bar. However, this strategy has advantages compared to solvent-based routes. For instance, solvents like methanol or ethanol are typically not inert and are incorporated in the products (alkylation). ${ }^{40}$ Furthermore, the use of a solvent complicates product workup and needs the introduction of an efficient solvent recycling strategy to improve the techno-economic viability of the process.

Early studies on the catalytic hydrotreatment of a number of lignins (including Kraft lignin) using NiMo catalysts on aluminosilica as the support in the absence of an external solvent were reported by Meier et al. ${ }^{42}$ Oil yields of up to 61.6 wt $\%$ were reported. In the case of organocell lignin, the monomer yield was $21.8 \mathrm{wt} \%$. Related hydrotreatment studies were reported by Oasmaa et al. using a variety of technical lignins. ${ }^{43}$ The highest oil yield was $71 \mathrm{wt} \%$, obtained for an organosolv lignin using a physical mixture of NiMo on aluminosilica and $\mathrm{Cr}_{2} \mathrm{O}_{3}$. The amount of low molecular weight compounds was also detemined and was between 14 and $38 \mathrm{wt}$ $\%$ on lignin intake. Best results were obtained using Kraft lignin. Recently, Kloekhorst et al. reported catalytic hydrotreatment studies using a pyrolytic lignin from a forestry residue and Alcell lignin with $\mathrm{Ru} / \mathrm{C}$ as the catalyst. ${ }^{44}$ For forestry residue pyrolytic lignin 75 wt \% of lignin oil was obtained. Detailed analysis by advanced GC methods showed that the oil contained high amounts of monomeric alkyl phenolics (20.5 wt \%) and aromatics (14.1 wt \%). Supported noble metal catalysts ( $\mathrm{Ru}, \mathrm{Pd}$, and $\mathrm{Cu}$ catalysts) have also been applied for the catalytic hydrotreatment of Alcell lignin (batch, $400{ }^{\circ} \mathrm{C}, 100$ bar $\mathrm{H}_{2}$ at $\mathrm{RT}$ for $\left.4-8 \mathrm{~h}\right) .{ }^{45} \mathrm{Ru} / \mathrm{C}$ gave the best results in terms of lignin oil yield ( $72.8 \mathrm{wt} \%$ yield based on lignin intake) and total monomers yield (29.7\%, of which $12.2 \%$ alkylphenolics, $5.2 \%$ aromatics, $10.1 \%$ overhydrogenated product (alkanes)). Recently, we reported the use of bimetallic sulfided NiMo and CoMo catalysts on various supports $\left(\mathrm{Al}_{2} \mathrm{O}_{3}, \mathrm{ZSM}-5, \mathrm{AC}, \mathrm{MgO}-\mathrm{La}_{2} \mathrm{O}_{3}\right)$ for Kraft lignin hydrotreatment in the absence of an external solvent (batch, $350{ }^{\circ} \mathrm{C}, 100$ bar $\mathrm{H}_{2}$ at RT for $\left.4 \mathrm{~h}\right){ }^{46}$ Best results in terms of oil and monomer yield were obtained with the sulfided $\mathrm{NiMo} / \mathrm{MgO}-$ $\mathrm{La}_{2} \mathrm{O}_{3}$ catalyst, giving $87 \%$ lignin conversion and $26.4 \mathrm{wt} \%$ of monomers on lignin intake, of which $15.7 \%$ were phenolics and $5.9 \%$ aromatics. Very recently, we reported the use of ironbased catalysts for the hydrotreatment of Kraft lignin in the absence of the external solvent. ${ }^{47}$ Various types of iron catalysts were explored; examples include limonite ore, Goethite, iron-nickel oxide $\left(\mathrm{Fe}_{2} \mathrm{O}_{3}-\mathrm{NiO}\right)$, iron oxide $\left(\mathrm{Fe}_{2} \mathrm{O}_{3}\right)$, and iron disulfide $\left(\mathrm{FeS}_{2}\right)$. The best results were obtained with limonite at $450{ }^{\circ} \mathrm{C}$, giving 31 wt \% of monomers on lignin intake, of which $17 \%$ were alkylphenolics and $8 \%$ aromatics.

The major disadvantage of the use of the sulfided NiMo/ CoMo catalysts is the requirement to introduce sulfided reagents to maintain activity and stability of the catalyst. Recently, transition metal phosphide catalysts have been introduced for hydrotreatment reactions ${ }^{49-52}$ and shown to be attractive alternatives for expensive noble metal catalysts. ${ }^{53,54}$ One of the advantages of this class of catalysts is that the use of a sulfur-introducing reagent is not required to maintain activity.

We here report the use of mono- and bimetallic phosphide catalysts with $\mathrm{Ni}, \mathrm{Mo}$, and $\mathrm{W}$ as the active metals for the catalytic hydrotreatment of Kraft lignin in the absence of an external solvent to obtain value-added chemicals like phenols and aromatics. Activated carbon (AC) was used as the support as previous research from our group on the hydrotreatment of Kraft lignin using sulfided NiMo and CoMo catalyst on different supports showed that char formation is lowest when using AC. ${ }^{46}$ A series of mono- and bimetallic phosphide catalysts was prepared and characterized by XRD, nitrogen physisorption, and TEM analysis. The catalysts were evaluated for the catalytic hydrotreatment of Kraft lignin, and process conditions such as temperature, reaction time, and catalyst loading were optimized to maximize monomer yields. The lignin oils after hydrotreatment were analyzed in detail by various techniques such as GPC, GC-MS/FID, GC $\times \mathrm{GC},{ }^{13} \mathrm{C}$ NMR, and CHNS analysis. Finally, the performance of the phosphide-based catalyst is compared with data available in the literature for lignin hydrotreatments without the use of an external solvent.

\section{EXPERIMENTAL SECTION}

Materials. Chemicals used in the study were of analytical grade and used as received. The activated carbon (AC) support was obtained from Merck, Germany. $\mathrm{Ni}\left(\mathrm{NO}_{3}\right)_{2} \cdot 6 \mathrm{H}_{2} \mathrm{O}$ (99\%), $\left(\mathrm{NH}_{4}\right)_{6} \mathrm{Mo}_{7} \mathrm{O}_{24} \cdot 4 \mathrm{H}_{2} \mathrm{O}$ (>99\%), $\left(\mathrm{NH}_{4}\right)_{6} \mathrm{H}_{2} \mathrm{~W}_{12} \mathrm{O}_{40} \cdot x \mathrm{H}_{2} \mathrm{O}$, and $\left(\mathrm{NH}_{4}\right)_{2} \mathrm{HPO}_{4}$ were purchased from Sigma-Aldrich. Dichloromethane, di- $n$-butylether (DBE), nitric acid, acetone, and THF were obtained from Boom B.V. Hydrogen (>99.99\%), nitrogen (>99.8\%), and $2 \%$ $\mathrm{O}_{2} / \mathrm{Ar}$ were purchased from Hoekloos. Indulin-AT (Kraft lignin) was from MWV specialty chemicals and provided by the Wageningen University and Research Center, The Netherlands (Dr. R. Gosselink). Indulin-AT is a purified form of Kraft pine lignin. The lignin content 


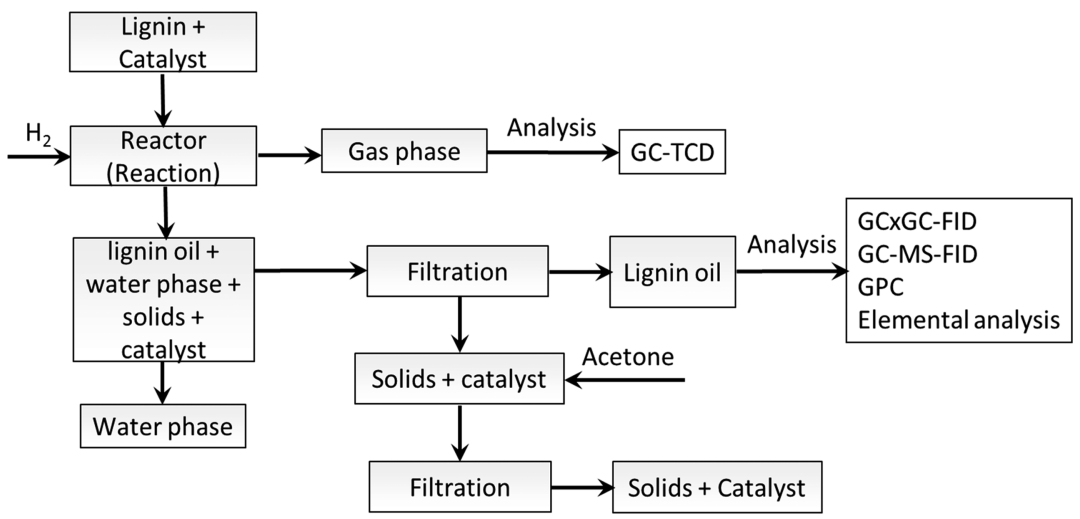

Figure 1. Overview of the experimental procedure for the hydrotreatment of Kraft lignin including product workup.

is $97 \mathrm{wt} \%$ on dry basis; the remainder is mainly ash. The elemental compostion is as follows: $\mathrm{C}=61.87 \mathrm{wt} \%, \mathrm{H}=5.98 \mathrm{wt} \%, \mathrm{~N}=0.69 \mathrm{wt}$ $\%, \mathrm{~S}=1.34 \mathrm{wt} \%, \mathrm{O}=30.12 \mathrm{wt} \%$. The molecular weight is reported to be about $4000 \mathrm{~g} / \mathrm{mol}^{55}$

Synthesis of the Metal Phosphide Catalysts on Activated Carbon. The NiP, MoP, WP, NiMoP, and NiWP supported on AC catalysts were prepared according to a literature procedure. ${ }^{53,56,57}$ The monometallic $\mathrm{Ni}-\mathrm{P}$ catalysts with $2.5 \mathrm{wt} \%$ of $\mathrm{Ni}$ and 2.6 wt \% of $\mathrm{P}$ was prepared as follows: $\mathrm{Ni}\left(\mathrm{NO}_{3}\right)_{2} \cdot 6 \mathrm{H}_{2} \mathrm{O}(0.61 \mathrm{~g})$ was dissolved in deionized water $(10 \mathrm{~mL})$. $\left(\mathrm{NH}_{4}\right)_{2} \mathrm{HPO}_{4}(0.55 \mathrm{~g})$ dissolved in deionized water $(10 \mathrm{~mL})$ was added to the nickel nitrate solution. The resulting precipitate was dissolved by the addition of a few drops of nitric acid. AC ( $4.75 \mathrm{~g})$ was added to the solution, and subsequently, the excess of water was removed by evaporation. The resulting solid was dried in an oven overnight at $110^{\circ} \mathrm{C}$. The catalyst was reduced in pure hydrogen flow $\left(100 \mathrm{~mL} \mathrm{~min}{ }^{-1} \mathrm{~g}^{-1}\right)$ at $650{ }^{\circ} \mathrm{C}$ for $2 \mathrm{~h}$ with a heating rate of $5{ }^{\circ} \mathrm{C} \mathrm{min}^{-1}$ and cooled to RT in a hydrogen flow. The catalyst was subsequently passivated under a flow of $2 \% \mathrm{O}_{2} / \mathrm{Ar}$ for 2 $\mathrm{h}$. The resulting catalyst is denoted as $5 \mathrm{NiP} / \mathrm{AC}$, where 5 indicates the sum of the weight percentages of $\mathrm{Ni}$ and $\mathrm{P}(\mathrm{Ni}=2.5 \mathrm{wt} \%, \mathrm{P}=2.6 \mathrm{wt}$ $\%$, corresponding with a molar ratio of Ni:P $=1: 2)$. Similarly, $15 \mathrm{MoP} / \mathrm{AC}$ (Mo 9.1 wt \%, P 5.9 wt $\%$ with a mole ratio of Mo:P = $1: 2$ ), 15WP/AC (mole ratio $\mathrm{W}: \mathrm{P}=1: 2$; W $11.2 \mathrm{wt} \%$, P 3.8 wt \%), $20 \mathrm{NiMoP} / \mathrm{AC}$ (Ni 5.6 wt \%, Mo 9.1 wt \%, P 5.9 wt \% with a mole ratio of Ni:Mo:P = 1:1:2), and 20NiWP/AC (Ni $3.9 \mathrm{wt} \%, \mathrm{~W} 12.3 \mathrm{wt}$ $\%$, P 4.1 wt \% with a mole ratio of Ni:W:P $=1: 1: 2)$ catalysts were prepared with the appropriate precursors. In the case of bimetallic phosphide catalysts, the metal precursor solutions were mixed together, followed by addition of an aqueous solution of $\left(\mathrm{NH}_{4}\right)_{2} \mathrm{HPO}_{4}$.

Experimental Procedure for the Catalytic Hydrotreatment of Kraft Lignin. All catalytic hydrotreatment reactions were performed in a batch autoclave (100 mL, Parr Instruments Co., stainless steel type 316 ). The reactor was surrounded by an aluminum block containing electrical heating elements and channels allowing the flow of cooling water. The reactor content was stirred mechanically using a gas-induced Rushton turbine. The temperature and pressure in the reactor were monitored online and logged on a PC.

The hydrotreatment and workup procedure is schematically shown in Figure 1. Initially, the reactor was loaded with Kraft lignin (15 g) and catalyst ( $0.75 \mathrm{~g}, 5 \mathrm{wt} . \%$ on lignin). Subsequently, the reactor was flushed with hydrogen to expel air and pressurized to 120 bar at room temperature for leak testing. After the leak test, the pressure was reduced to 100 bar. Stirring was started $(1200 \mathrm{rpm})$, and the reactor content was heated to the desired temperature $\left(400-500{ }^{\circ} \mathrm{C}\right)$ with a heating rate of about $10{ }^{\circ} \mathrm{C} \mathrm{min}$. The reaction time was set to zero when the desired temperature was reached. After completion of the reaction, the reactor was cooled to room temperature with a rate of about $10{ }^{\circ} \mathrm{C} \mathrm{min}^{-1}$. The pressure at room temperature was recorded to determine the amount of gas-phase components produced during the reaction. The produced gas was collected in a $3 \mathrm{~L}$ Tedlar gas bag to determine the composition. For all reactions, the clear formation of two separate liquid phases was observed viz. a lignin oil (light phase) and a water phase (see the Supporting Information, Figure S1). The product workup procedure is given in Figure 1. After reaction, the organic and water phases were filtered through a microfilter and separated by decanting. The solid was thoroughly washed with acetone and dried to determine the solid yield.

The product yield, solid (i.e., unconverted lignin and/or repolymerized product) and mass balances were calculated based on initial lignin intake using eqs $1-4$. All product yields (lignin oil, char, and gas) are given as wt \% on lignin intake.

$$
\begin{aligned}
& \operatorname{conversion}(\%)=\frac{\text { initial lignin intake }(\mathrm{g})-\operatorname{solid}(\mathrm{g})}{\text { initial lignin intake }(\mathrm{g})} \times 100 \\
& \text { product yield }(\%)=\frac{\text { amount of product }(\mathrm{g})}{\text { initial lignin intake }(\mathrm{g})} \times 100 \\
& \operatorname{solid}(\%)=\frac{\operatorname{solid}(\mathrm{g})}{\text { initial lignin intake }(\mathrm{g})} \times 100 \\
& \text { mass balance }(\%)=\frac{\sum \text { products }(\mathrm{g})}{\text { initial lignin intake }(\mathrm{g})} \times 100
\end{aligned}
$$

Analytical Procedures. The gas phase after reaction was collected and stored in a gas bag (SKC Tedlar $3 \mathrm{~L}$ sample bag $\left.\left(9.5^{\prime \prime} \times 10^{\prime \prime}\right)\right)$ with a polypropylene septum fitting. The gas-phase composition was analyzed using a GC-TCD (Hewlett-Packard 5890 Series II GC equipped with a Poraplot $\mathrm{Q} \mathrm{Al}_{2} \mathrm{O}_{3} / \mathrm{Na}_{2} \mathrm{SO}_{4}$ column and a molecular sieve ( $5 \AA$ ) column). The injector temperature was set at $150{ }^{\circ} \mathrm{C}$ and the detector temperature at $90{ }^{\circ} \mathrm{C}$. The oven temperature was kept at $40{ }^{\circ} \mathrm{C}$ for $2 \mathrm{~min}$, then heated up to $90{ }^{\circ} \mathrm{C}$ at $20^{\circ} \mathrm{C} \mathrm{min}^{-1}$, and kept at this temperature for $2 \mathrm{~min}$. A reference gas was used to quantify the results $\left(55.19 \% \mathrm{H}_{2}, 19.70 \% \mathrm{CH}_{4}, 3.00 \% \mathrm{CO}, 18.10 \%\right.$ $\mathrm{CO}_{2}, 0.51 \%$ ethylene, $1.49 \%$ ethane, $0.51 \%$ propylene, and $1.5 \%$ propane).

Lignin oils were analyzed by GC-MS-FID using a Quadruple Hewlett-Packard 6890 MSD attached to a Hewlett-Packard 5890 GC equipped with a sol-gel capillary column $(60 \mathrm{~m} \times 0.25 \mathrm{~mm}$ i.d. and a $0.25 \mu \mathrm{m})$. The injector temperature was set at $250{ }^{\circ} \mathrm{C}$. The oven temperature was kept at $40^{\circ} \mathrm{C}$ for $5 \mathrm{~min}$, heated to $250{ }^{\circ} \mathrm{C}$ at a rate of $3{ }^{\circ} \mathrm{C} \mathrm{min}{ }^{-1}$, and then held at $250{ }^{\circ} \mathrm{C}$ for $10 \mathrm{~min}$.

GC $\times$ GC-FID analysis was performed using a trace GC $\times$ GC from Interscience equipped with a cryogenic trap system and two columns (a $30 \mathrm{~m} \times 0.25 \mathrm{~mm}$ i.d. and a $0.25 \mu \mathrm{m}$ film of RTX-1701 capillary column connected by a meltfit to a $120 \mathrm{~cm} \times 0.15 \mathrm{~mm}$ i.d. and a 0.15 $\mu \mathrm{m}$ film Rxi-5Sil MS column). An FID detector was used. A dual-jet modulator was applied using carbon dioxide to trap the samples. Helium was used as the carrier gas (continuous flow $0.8 \mathrm{~mL} / \mathrm{min}$ ). The injector temperature and FID temperature were set at $280{ }^{\circ} \mathrm{C}$. The oven temperature was kept at $40^{\circ} \mathrm{C}$ for $5 \mathrm{~min}$ and then heated up to $280{ }^{\circ} \mathrm{C}$ at a rate of $3{ }^{\circ} \mathrm{C} \min ^{-1}$. The pressure was set at $70 \mathrm{kPa}$ at $40{ }^{\circ} \mathrm{C}$. The modulation time was $6 \mathrm{~s}$. For both GCXGC-FID and 
GC-MS-FID analyses, the samples were diluted with tetrahydrofuran (THF) and 500 ppm of di- $n$-butyl ether (DBE) was added as an internal standard. Detailed information on quantification of the amounts of monomers is given in ref 46 and the Supporting Information.

GPC analysis of the samples was performed using a HP1100 equipped with three MIXED-E columns $(300 \times 7.5 \mathrm{~mm}$ PL gel $3 \mu \mathrm{m})$ in series using a GBC LC 1240 RI detector. Average molecular weight calculations were performed using the PSS WinGPC Unity software from Polymer Standards Service. The following conditions were used: THF as the eluent at a flow rate of $1 \mathrm{~mL} \mathrm{~min}{ }^{-1}, 140 \mathrm{bar}$, a column temperature of $40{ }^{\circ} \mathrm{C}, 20 \mu \mathrm{L}$ injection volume, and a $10 \mathrm{mg} \mathrm{mL}^{-1}$ sample concentration. Toluene was used as a flow marker. Polystyrene samples with different molecular weights were used as the calibration standards.

TGA analyses were performed using a TGA 7 from PerkinElmer. The samples were heated under a nitrogen atmosphere (flow of 50 $\mathrm{mL} / \mathrm{min}$ ) with a heating rate of $10{ }^{\circ} \mathrm{C} / \mathrm{min}$ and temperature ramp of $30-900{ }^{\circ} \mathrm{C}$.

${ }^{13} \mathrm{C}$ NMR spectra were acquired at $25{ }^{\circ} \mathrm{C}$ using an Agilent 400 $\mathrm{MHz}$ spectrometer. Approximately $0.1 \mathrm{~g}$ of lignin oil was dissolved in $0.6 \mathrm{~mL}$ of dimethylsulfoxide- $d_{6}$ (DMSO). The number of scans was 2048 with a relaxation time of $5 \mathrm{~s}$. The data were processed using the MestReNova software.

Elemental analysis (C, H, N, and S) were performed using a Euro Vector $3400 \mathrm{CHN}-\mathrm{S}$ analyzer. The oxygen content was determined by difference. All experiments were carried out in duplicate, and the average value is provided.

TOC (total organic carbon) in the aqueous phase was determined with a Shimadzu TOC-VCSH TOC analyzer equipped with an OCT1 sampler port.

Transmission electronic microscopy (TEM) images were obtained using a Philips CM12 operated at an acceleration voltage of $120 \mathrm{kV}$. Samples for TEM measurements were ultrasonically dispersed in ethanol and subsequently deposited on mica grid coated with carbon.

$\mathrm{X}$-ray diffraction data of the catalysts were recorded on a Bruker D8 advance diffractometer using $\mathrm{Cu} K \alpha$ radiation $(\lambda=0.1544 \mathrm{~nm})$ at 40 $\mathrm{kV}$. XRD patterns were measured in reflection geometry in the $2 \theta$ range between $5^{\circ}$ and $80^{\circ}$ with a step size of $0.04^{\circ}$.

Statistical Modeling. Multivariable regression was used to model the experimental data, and for this purpose the Design Expert Version 8.0.0 software package was used. The experimental data were modeled using eq 5 .

$$
y=b_{0}+\sum_{i=1}^{2} b_{i} x_{i}+\sum_{i=1}^{2} b_{i i} x_{i}^{2}+\sum_{i=1}^{1} \sum_{j=i+1}^{2} b_{i j} x_{i j}+e
$$

Here $y$ is a dependent variable (lignin oil yield), $x_{i}$ and $x_{j}$ are the independent variables (temperature $\left({ }^{\circ} \mathrm{C}\right)$ and reaction time $\left.(\mathrm{h})\right), b_{0}$, $b_{i}, b_{i j}$ and $b_{i j}$ are the regression coefficients of the model, and $e$ is the error of the model. The regression equations were obtained by backward elimination of statistically nonsignificant parameters. A parameter was considered statistically relevant when the $p$ value was less than 0.05 .

\section{RESULTS AND DISCUSSION}

Catalyst Synthesis and Characterization. The NiP, MoP, WP, NiMoP, and NiWP supported on AC catalysts were prepared according to a procedure reported in the literature ${ }^{53,56,57}$ and involves a wet impregnation procedure with $\left(\mathrm{NH}_{4}\right)_{2} \mathrm{HPO}_{4}$ as the phosphide source. The molar ratio of metal to $\mathrm{P}$ was in all cases set to $1: 2$. For the bimetallic compounds, the soluble metal precursors were mixed before addition to the AC. All catalysts were reduced with hydrogen at $650{ }^{\circ} \mathrm{C}$ for $2 \mathrm{~h}$, followed by a passivation step at room temperature with $2 \% \mathrm{O}_{2}$ in air. Catalyst coding, the exact elemental composition of the catalysts, and relevant properties are given in Table 2. XRD patterns of Ni-, Mo-, and W-
Table 2. Composition and Textural Properties of the Metal Phosphide Catalysts

\begin{tabular}{|c|c|c|c|c|}
\hline catalyst & $\begin{array}{c}\text { molar ratio } \\
\mathrm{Ni}(\mathrm{Mo} \text { or } \mathrm{W}): \mathrm{P}\end{array}$ & $\begin{array}{c}\text { metal and P } \\
\text { content } \\
(\text { wt } \%)\end{array}$ & $\begin{array}{l}\text { avg. pore } \\
\text { diameter } \\
(\mathrm{nm})\end{array}$ & $\begin{array}{c}\text { BET } \\
\text { surface } \\
\text { area } \\
\left(\mathrm{m}^{2} / \mathrm{g}\right)\end{array}$ \\
\hline $\mathrm{AC}$ & & & 3.27 & 752 \\
\hline $5 \mathrm{NiP} / \mathrm{AC}$ & $1: 0: 2$ & $\begin{array}{l}\text { Ni } 2.5, \mathrm{P} \\
2.6\end{array}$ & 3.24 & 750 \\
\hline $15 \mathrm{MoP} / \mathrm{AC}$ & $0: 1: 2$ & $\begin{array}{l}\text { Mo 9.1, P } \\
5.9\end{array}$ & 3.26 & 502 \\
\hline $15 \mathrm{WP} / \mathrm{AC}$ & $0: 1: 2$ & $\begin{array}{l}\text { W 11.2, P } \\
3.8\end{array}$ & 3.33 & 540 \\
\hline $20 \mathrm{NiMoP} / \mathrm{AC}$ & $1: 1: 2$ & $\begin{array}{r}\text { Ni 5.6, Mo } \\
\text { 9.1, P 5.9 }\end{array}$ & 3.35 & 381 \\
\hline 20NiWP/AC & $1: 1: 2$ & $\begin{array}{l}\text { Ni } 3.9, \mathrm{~W} \\
\text { 12.3, P } \\
4.1\end{array}$ & 3.25 & 540 \\
\hline
\end{tabular}

containing mono- and bimetallic catalysts are shown in the Supporting Information (Figure S2) as well as representative TEM images (Figure S3). Nitrogen adsorption-desorption isotherms and pore size distriution curves are shown in Figure S4 (Supporting Information).

Catalytic Hydrotreatment of Kraft Lignin Using Metal Phosphide Catalysts. Product Yields and Mass Balances for Experiments at $400{ }^{\circ} \mathrm{C}$. In the first phase of the research, hydrotreatment experiments of Kraft lignin were performed at $400{ }^{\circ} \mathrm{C}$ using the $\mathrm{Ni}$-, $\mathrm{W}$-, and Mo-based mono- and bimetallic phosphides supported on activated carbon. The major product is a lignin oil with yields in the range of $39.2-64.3 \%$ on lignin intake (Table 3 ). Other products include a water phase (about

Table 3. Lignin Oil Yields and Mass Balances for Catalytic Hydrotreatment of Kraft Lignin Using Mono- and Bimetallic Phosphide Catalysts ${ }^{a}$

\begin{tabular}{lcccccc}
\multicolumn{1}{c}{ catalyst } & $\begin{array}{c}\text { oil } \\
\text { yield } \\
(\%)^{b}\end{array}$ & $\begin{array}{c}\text { gas } \\
\text { phase } \\
(\%)^{b}\end{array}$ & $\begin{array}{c}\text { water } \\
(\%)^{b}\end{array}$ & $\begin{array}{c}\text { solids } \\
(\%)^{b}\end{array}$ & $\begin{array}{c}\text { mass } \\
\text { balance } \\
(\%)^{b}\end{array}$ & $\begin{array}{c}\text { carbon } \\
\text { balance } \\
(\%)^{c}\end{array}$ \\
$5 \mathrm{NiP} / \mathrm{AC}$ & 39.2 & 9.4 & 18.4 & 22.9 & 90 & 56 \\
$15 \mathrm{MoP} / \mathrm{AC}$ & 61.2 & 8.4 & 21.0 & 5.1 & 96 & 90 \\
$15 \mathrm{WP} / \mathrm{AC}$ & 60.8 & 9.5 & 20.4 & 6.2 & 97 & 91 \\
$20 \mathrm{NiMoP} / \mathrm{AC}$ & 64.3 & 10.1 & 19.8 & 5.1 & 99 & 96 \\
$20 \mathrm{NiWP} / \mathrm{AC}$ & 59.3 & 10.3 & 20.2 & 8.2 & 98 & 90
\end{tabular}

${ }^{a}$ Reaction conditions: Kraft lignin, $15 \mathrm{~g}$; catalyst, $0.75 \mathrm{~g} ; 400{ }^{\circ} \mathrm{C}$; hydrogen pressure of $100 \mathrm{bar}$ at RT; $4 \mathrm{~h} ; 1200 \mathrm{rpm}$. ${ }^{b}$ Percent is on weight basis of lignin intake. ${ }^{c}$ Including carbon content of gas phase, lignin oil, and water phase, excluding carbon content of solid phase.

20\%), solid residue (char 5.1-22.9\%), and gas phase (8$10 \%)$. The mass balances closure excluding hydrogen consumption is very good with values between $90 \%$ and $99 \%$ (Table 3, see also Supporting Information (Table S1) for a mass balance including hydrogen consumption). Carbon balances were also calculated based on the measured carbon content in the gas phase (GC), lignin oil (elemental analyses), and water phase (total organic carbon, TOC), though excluding the carbon content of the solid phase. The TOC in the water phase was very low (less than $0.07 \mathrm{wt} \%$ on lignin) and as such is not a major loss of carbon for the process. The carbon balance closure is $>90 \%$ for most of the catalysts (Table 3 ), the only exception being $5 \mathrm{NiP} / \mathrm{AC}$ (56\%), which is due to the high amount of solids formed when using this catalyst. 
In the absence of a catalyst, the main product is a solid residue ( $>50$ wt \%), with by far lower amounts of a lignin oil ( 9.4 wt \% on ligin) than obtained for the catalytic recations. As such, a catalyst is required for good depolymerization activity, though some thermal depolymerization also occurs.

The worst performance was found for the monometallic $5 \mathrm{NiP} / \mathrm{AC}$ catalyst, giving a low lignin oil yield (39.2\%) and high amounts of solids (22.9\%). In the case of Mo- and Wcontaining monometallic catalysts, the lignin oil yields are considerably higher (about 60\%) and also less residue was observed after reaction. However, precise comparsion of the data is not possible at this stage due to the difference in metal content.

When comparing the bimetallic catalysts, the highest lignin oil yield $(64.3 \%)$ was obtained for bimetallic $20 \mathrm{NiMoP} / \mathrm{AC}$ catalyst, indicating that Mo-containing phosphide catalysts exhibit better performance than the W-based catalyst.

Characterization of the Lignin Oils. The elemental composition of the lignin oils obtained at $400{ }^{\circ} \mathrm{C}$ were determined by elemental analysis. The oxygen and hydrogen contents are provided in the form of a van Krevelen diagram in Figure 2. The $\mathrm{O} / \mathrm{C}$ and $\mathrm{H} / \mathrm{C}$ values for the lignin oils are all

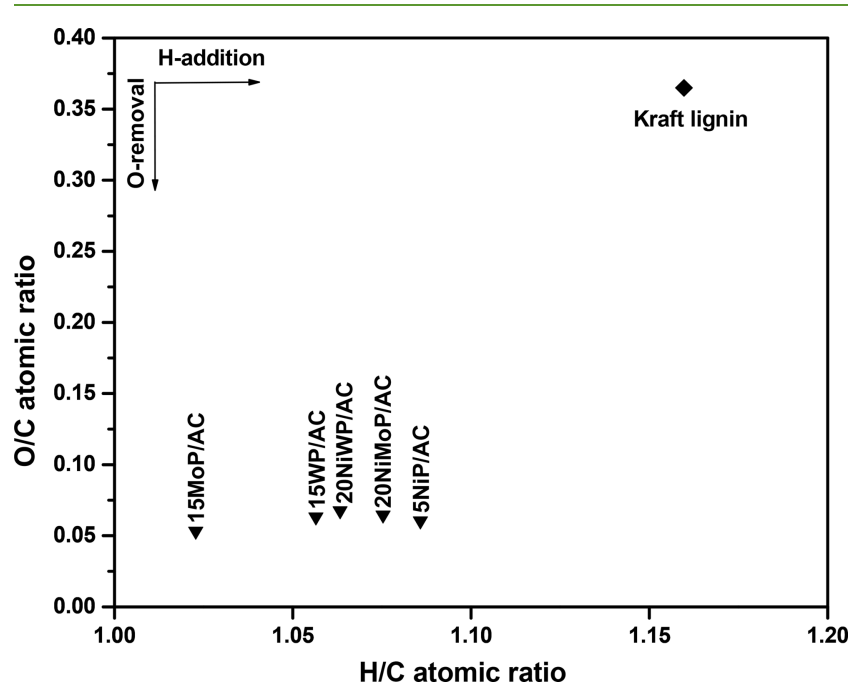

Figure 2. van Krevelen plot for lignin oils obtained at $400{ }^{\circ} \mathrm{C}$. Reaction conditions: Kraft lignin, 15 g; catalyst, 0.75 g; $400{ }^{\circ} \mathrm{C}$; hydrogen pressure of $100 \mathrm{bar}$ at RT; $4 \mathrm{~h} ; 1200 \mathrm{rpm}$.

present in a relatively narrow range with an $\mathrm{O} / \mathrm{C}$ of about 0.05 and an $\mathrm{H} / \mathrm{C}$ between 1.02 and 1.07. The $\mathrm{O} / \mathrm{C}$ value is considerably lower than for the Kraft lignin feed $(\mathrm{O} / \mathrm{C}=0.36)$, indicating substantial removal of bound oxygen by, for instance, hydrodeoxygenation reactions to form water. The range of $\mathrm{H} / \mathrm{C}$ and $\mathrm{O} / \mathrm{C}$ values for lignin oils are in between that of alkylphenolics and aromatics, which indicates the presence of significant amounts of such component classes. This is confirmed by detailed analysis of the lignin oils (vide infra). The sulfur content in all of the lignin oils was determined and was shown to be about $0.01 \mathrm{wt} \%$ for all samples. The Kraft lignin used for this study contains $1.34 \mathrm{wt}$ $\%$ sulfur, indicating that hydrodesulfurization takes place to a considerable extent. Furthermore, incorporation of $S$ in the solid residue is also an option, though this was not investigated.

GPC chromatograms for the lignin oils obtained for the various metal phosphide catalysts at $400{ }^{\circ} \mathrm{C}$ are presented in
Figure 3. For all of the lignin oils sharp intense peaks are observed in the low molecular weight region $(80-150 \mathrm{~g} / \mathrm{mol})$,

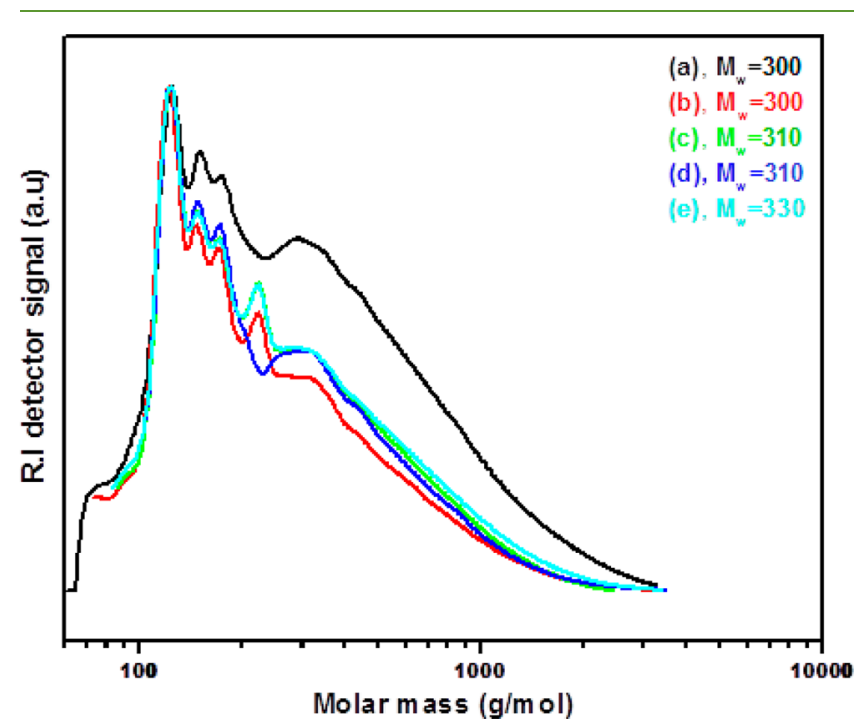

Figure 3. Gel permeation chromatograms of lignin oils obtained for over various phosphide catalysts at $400{ }^{\circ} \mathrm{C}$ : (a) $5 \mathrm{NiP} / \mathrm{AC}$, (b) $15 \mathrm{MoP} / \mathrm{AC}$, (c) $15 \mathrm{WP} / \mathrm{AC}$, (d) $20 \mathrm{NiMoP} / \mathrm{AC}$, and (e) $20 \mathrm{NiWP} /$ AC.

indicating the presence of a significant amount of low molecular weight monomers. The average molecular weight for the original Kraft lignin determined by our GPC method is $985 \mathrm{~g} / \mathrm{mol}$, indicating that the lignin oils are considerably depolymerized. However, the extent of depolymerization is underestimated as our molecular weight data for the $\mathrm{Kraft}$ lignin are by far lower than reported in the literature (4000 g/ $\mathrm{mol}$ ). The low value for the Kraft lignin feed found by us is due to a limited solubilty in the eluent used for the GPC analysis (THF).

GC analysis was performed on the product oils to gain insights into the molecular composition. A representative GCMS spectrum is given in the Supporting Information (Figure S5) and shows the presence of a large number of compounds belonging to various organic component classes. Quantification of the monomers present in the lignin oils was done by GC $\times$ GC analysis using $n$-dibutylether as an internal standard. The main advantage of this technique is better separation of products allowing clustering of component classes (alkylphenolics, aromatics, alkanes, etc.). A typical GC $\times$ GC chromatogram is shown in the Supporting Information (Figure S6), where the different regions for the various classes of monomers can be clearly seen. The total monomer yield ( $\mathrm{GC} \times \mathrm{GC}$ analysis) for the catalytic hydrotreatment reactions performed at $400{ }^{\circ} \mathrm{C}$ is shown in Figure 4. Highest total monomer yields were obtained for the Mo-containing phosphide catalysts, with values up to $40 \mathrm{wt} \%$ on lignin intake. The main product class is alkylphenolics, with yields of about 22 wt \% on lignin intake for the Mo-containing catalysts, followed by aromatics, with yields of about $8 \mathrm{wt} \%$. In addition, some overhydrogenated products like cyclic and linear alkanes are present.

The lignin oil samples were also characterized using ${ }^{13} \mathrm{C}$ NMR. This method has the advantage over GC methods that all of the components in the sample are identifiable and not only the low molecular weight fraction detectable by GC. Figure 5 shows the spectra of the parent Kraft lignin and the 


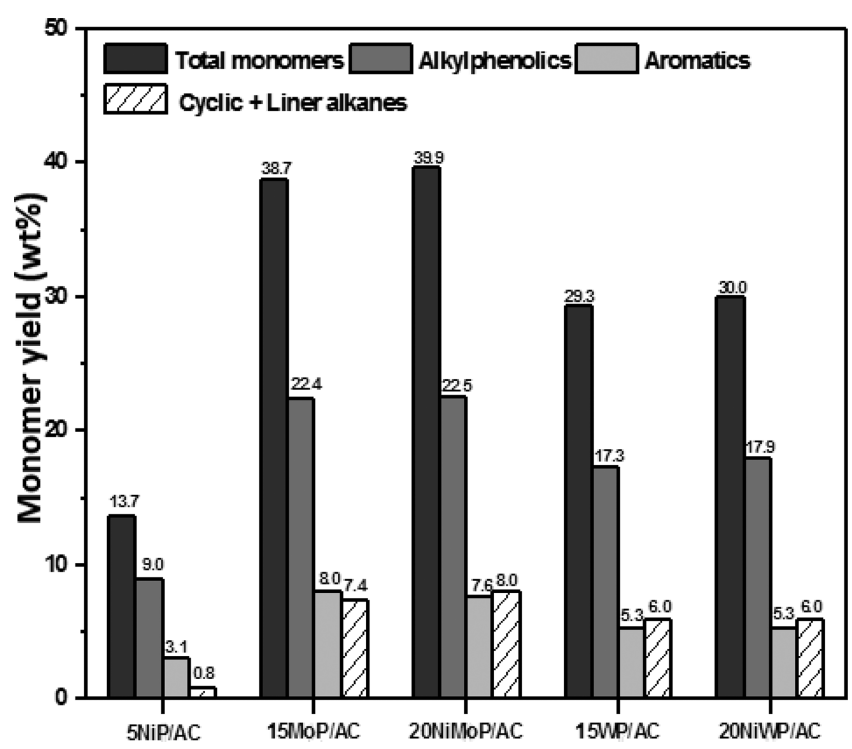

Figure 4. Monomer yield (wt \% on lignin intake) for hydrotreatment reactions carried out at $400{ }^{\circ} \mathrm{C}$.

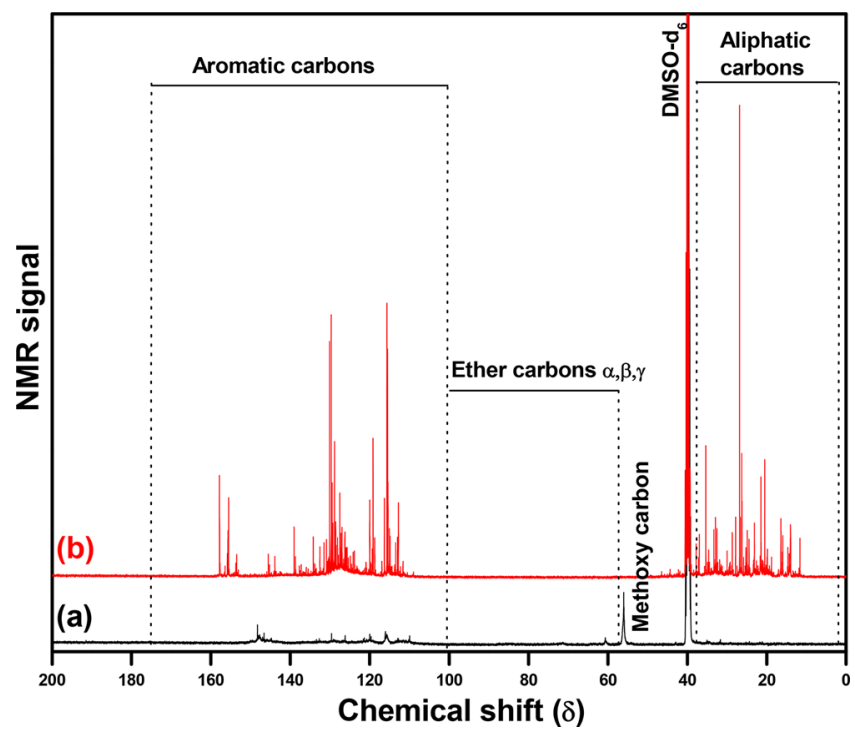

Figure 5. ${ }^{13} \mathrm{C}$ NMR spectra in DMSO- $d_{6}$ of (a) Kraft lignin and (b) lignin oil obtained using $20 \mathrm{NiMoP} / \mathrm{AC}$ at $400{ }^{\circ} \mathrm{C}$.

lignin oil obtained at $400{ }^{\circ} \mathrm{C}$ using the bimetallic $20 \mathrm{NiMoP} /$ $\mathrm{AC}$ catalyst. Information about chemical reactions occurring during the hydrotreatment process can be obtained by integration of peak intensities in chemical shift ranges belonging to carbon atoms with different chemical environments (aliphatics, $\delta 0-36 \mathrm{ppm}$; methoxy, $\delta 52-58 \mathrm{ppm}$; ether bonds, $\delta 58-100 \mathrm{ppm}$; aromatics, $\left.\delta 100-160 \mathrm{ppm}^{44}\right)$. Kraft lignin exhibits peaks at $\delta 50.1$ and $\delta 60.5 \mathrm{ppm}$, corresponding to methoxy and ether carbons, respectively. A number of peaks are observed in the range from $\delta 107$ to $152 \mathrm{ppm}$, related to aromatic carbons in the lignin polymer. After the hydrotreatment reaction using the $20 \mathrm{NiMoP} / \mathrm{AC}$ catalyst, the peaks related to methoxy groups were not observed, indicating that most of the methoxy groups are removed during the process. In addition, typical resonances from the $\mathrm{C}-\mathrm{O}-\mathrm{C}$ linkages have also disappeared, suggesting that ether linkages are broken, leading to the formation of lower molecular weight components. Also, the intensity of the peaks in the aliphatic and aromatic region is relatively high in the hydrotreated Kraft lignin. The intense peaks in the $\delta 0-36 \mathrm{ppm}$ region are due to presence of alkyl chains (methyl, ethyl, and propyl, etc.) on the depolymerized products such as alkylphenolics, alkyl-substituted aromatics, and over-hydrogenated products.

Characterization of the Gas Phase. The gas-phase composition after reaction was determined by GC for all experiments performed at $400{ }^{\circ} \mathrm{C}$ (Table 3 ), and the data are given in the Supporting Information (Table S2). It was shown to consist of mainly unconverted hydrogen, $\mathrm{CO}_{2}(2.7-4.1 \mathrm{wt}$ $\%$ on lignin), $\mathrm{CO}(<0.2 \mathrm{wt} \%$ on lignin), and hydrocarbons, mainly in the form of $\mathrm{CH}_{4}$ (3.6-5.3 wt \% on lignin) and some of ethane (0.7-0.9 wt \% on lignin) and propane (0.5-0.7 wt \% on lignin). The gas-phase components may be formed by reactions involving the lignin (e.g., methoxy removal and formation of methane, decarbonylation), as well as subsequent gas-phase reactions (water-gas shift and $\mathrm{CO} / \mathrm{CO}_{2}$ hydrogenation). The formation of $\mathrm{H}_{2} \mathrm{~S}$ is anticipated based on the relatively harsh conditions and the presence of organic sulfur in the Kraft lignin feed, though it could not quantified by the GC method used in this study.

Optimization of Reaction Parameters. The mono- and bimetallic Mo-containing catalysts (15MoP/AC and $20 \mathrm{NiMoP} / \mathrm{AC}$ ) gave the highest amount of monomers based on GCXGC analysis. Hence, these catalysts were selected for further optimization studies with an emphasis on reaction temperature, reaction time, and catalyst loading. The yields of the various products (lignin oil, gas-phase components, and solid residue) were determined, and the lignin oils were characterized in detail.

Effect of Temperature and Reaction Time. The effect of temperature and reaction time was studied for temperatures in the range of $400-500{ }^{\circ} \mathrm{C}$ and reaction times between 0 and $8 \mathrm{~h}$. A reaction time of $0 \mathrm{~h}$ means that the batch reactor was heated to the predetermined reaction temperature and then immediately cooled to room temperature. The product yields and mass balances are provided in Table 4 . Very good mass balance closures $(>93 \%)$ were obtained for all reactions. It is evident that when the severity is increased (higher temperature, longer batch times), the lignin oil yield is decreased. This is particularly evident when comparing the lignin oil yield for the monometallic Mo catalyst, viz from 80.5 wt \% at the lowest severity $\left(400{ }^{\circ} \mathrm{C}, 0 \mathrm{~h}\right)$ to $37.2 \mathrm{wt} \%$ at a high severity $\left(450{ }^{\circ} \mathrm{C}\right.$, $4 \mathrm{~h}$ ). At high severity, the amount of solid increases, indicating that repolymerization of reactive fragments to solids becomes more prominent at higher severity. In addition, the formation of larger amounts of water at higher severities suggests a higher rate of hydrodeoxygenation reactions at these conditions. When comparing both catalysts, char formation was the lowest for the bimetallic $20 \mathrm{NiMoP} / \mathrm{AC}$ catalyst at all reaction temperatures and batch times. The only difference between both catalysts when regarding composition (Table 2) is the presence of $5 \mathrm{wt} \%$ of $\mathrm{Ni}$ in the bimetallic catalyst. As such, it appears that the addition of $\mathrm{Ni}$ to the $\mathrm{MoP} / \mathrm{AC}$ catalyst has a positive effect on performance.

The experimental data given in Table 4 for the best catalyst (20NiMoP/AC) were used as input for the development of a multivariable regression model for the lignin oil yield as a function of the temperature and batch time. The coefficients for the regression model are provided in Table S3 (Supporting Information), and relevant statistical data are given in Table S4 (Supporting Information). The model relation between process conditions and lignin oil yield is given by eq 6 . 
Table 4. Lignin Oil Yields and Mass Balances for the Hydrotreatment of Kraft Lignin Using Mono- and Bimetallic Mo-Based Catalysts $^{a}$

\begin{tabular}{|c|c|c|c|c|c|c|c|}
\hline catalyst & temp. $\left({ }^{\circ} \mathrm{C}\right)$ & time $(\mathrm{h})$ & oil yield $(\%)^{b}$ & gas phase $(\%)^{b}$ & water $(\%)^{b}$ & solid $(\%)^{b}$ & mass balance $(\%)^{b}$ \\
\hline 20NiMoP/AC & 350 & 4 & 61.7 & 5.4 & 11.8 & 4.5 & $85^{c}$ \\
\hline \multirow{4}{*}{ 15MoP/AC } & 400 & 0 & 80.5 & 7.5 & 7.8 & 2.9 & 99 \\
\hline & & 2 & 67.2 & 9.0 & 20.3 & 1.7 & 97 \\
\hline & & 4 & 61.2 & 8.4 & 21.0 & 5.1 & 96 \\
\hline & & 8 & 59.8 & 10.7 & 23.0 & 4.9 & 98 \\
\hline \multirow[t]{4}{*}{ 20NiMoP/AC } & 400 & 0 & 77.4 & 6.4 & 12.0 & 1.7 & 97 \\
\hline & & 2 & 67.2 & 8.6 & 19.7 & 4.0 & 99 \\
\hline & & 4 & 64.3 & 10.1 & 19.8 & 5.1 & 99 \\
\hline & & 8 & 64.5 & 9.8 & 20.3 & 3.5 & 98 \\
\hline $15 \mathrm{MoP} / \mathrm{AC}$ & 425 & 4 & 49.5 & 9.7 & 20.7 & 13.2 & 93 \\
\hline $20 \mathrm{NiMoP} / \mathrm{AC}$ & 425 & 4 & 55.7 & 14.4 & 21.5 & 7.6 & 99 \\
\hline \multirow[t]{3}{*}{$15 \mathrm{MoP} / \mathrm{AC}$} & 450 & 0 & 64.7 & 9.8 & 18.8 & 4.2 & 97 \\
\hline & & 1 & 51.1 & 11.5 & 20.0 & 12.5 & 95 \\
\hline & & 4 & 37.2 & 15.4 & 22.5 & 20.4 & 95 \\
\hline \multirow[t]{3}{*}{$20 \mathrm{NiMoP} / \mathrm{AC}$} & 450 & 0 & 62.7 & 9.2 & 20.3 & 5.1 & 97 \\
\hline & & 1 & 52.1 & 11.8 & 22.4 & 11.5 & 98 \\
\hline & & 4 & 42.1 & 13.7 & 22.8 & 17.7 & 96 \\
\hline $15 \mathrm{MoP} / \mathrm{AC}$ & 500 & 0 & 41.4 & 12.4 & 22.5 & 19.8 & 96 \\
\hline 20NiMoP/AC & 500 & 0 & 47.4 & 12.8 & 22.7 & 15.2 & 98 \\
\hline
\end{tabular}

${ }^{a}$ Reaction conditions: Kraft lignin, $15 \mathrm{~g}$; catalyst, $0.75 \mathrm{~g}$; hydrogen pressure of 100 bar at RT; $1200 \mathrm{rpm} .{ }^{b}$ Percent is wt $\%$ on lignin intake. ${ }^{c}$ Lower mass balance closure than experiments at higher temperatures due to the viscous nature of the product oil, which hampers isolation and separation.

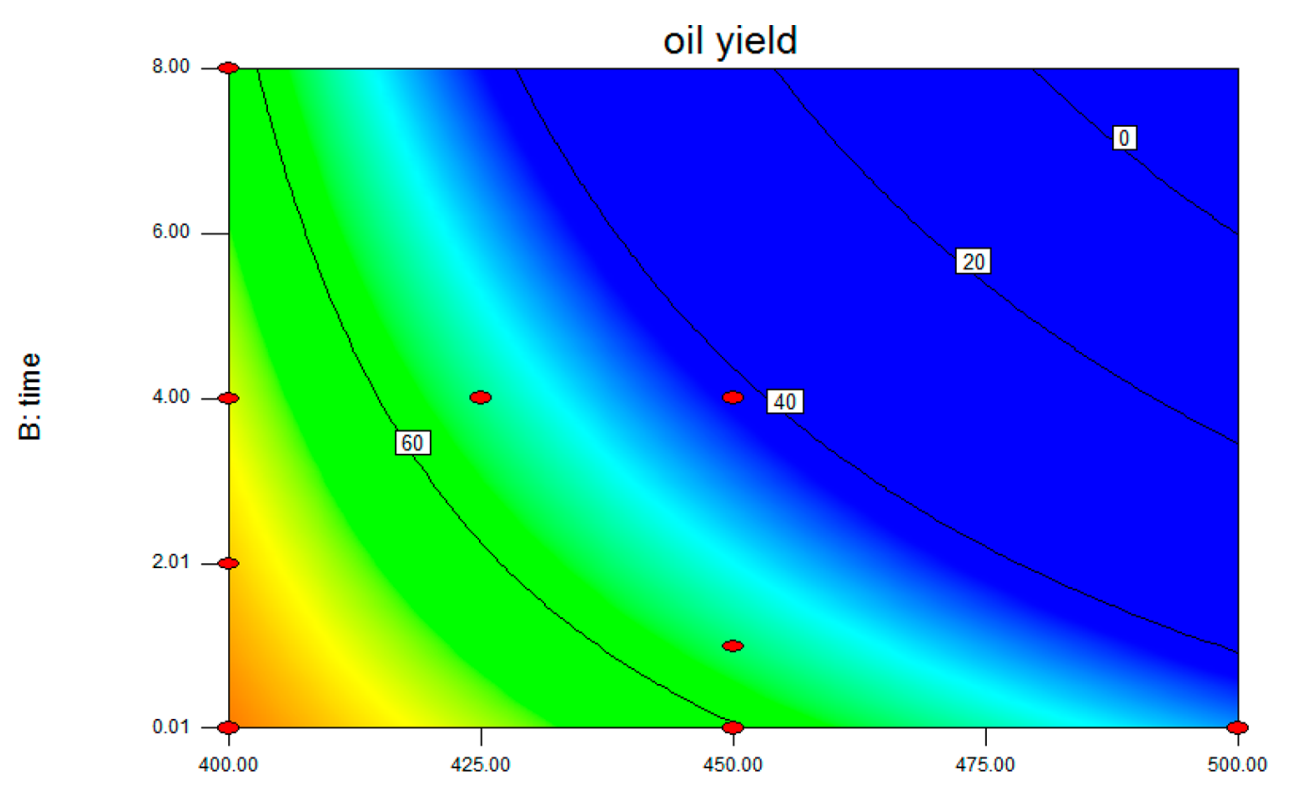

A: Temperature

Figure 6. Lignin oil yield (wt \% on lignin) versus temperature $\left({ }^{\circ} \mathrm{C}\right)$ and reaction time $(\mathrm{h})$.

oil yield $($ wt $\%)=+177.13-0.259 T+24.70 t-0.065 T t$

The $p$ value of the model is low $(<0.0024)$, which indicates that the model is statistically significant. The effects of the relevant process variables on the lignin oil yield are provided in the contour plot provided in Figure 6.

The data in Figure 6 clearly show that lowest severity is preferred for high lignin oil yields. However, the amount of lignin oil is not the only catalyst performance indicator; of higher interest is the amount of monomeric alkylphenolics and aromatics in the oil, the target product classes of this study. Therefore, all lignin oils were subjected to GPC and GC $\times$ GC analyses. The GPC chromatograms of the lignin oils obtained at various reaction temperatures and times for the bimetallic $20 \mathrm{MoP} / \mathrm{AC}$ catalyst are given in Figure 7 , whereas the ones for $15 \mathrm{MoP} / \mathrm{AC}$ are provided in the Supporting Information (Figure S7). The weight-average molecular weight values for all oils are given in Table 5 .

It is clear that the weight-average molecular weight is a function of the severity and that higher severity leads to lower molecular weight values. As such, depolymerization is more pronounced at higher temperatures. However, the amount of lignin oil is also reduced at higher severity due to repolymerization and gasification reactions. As such, a delicate 


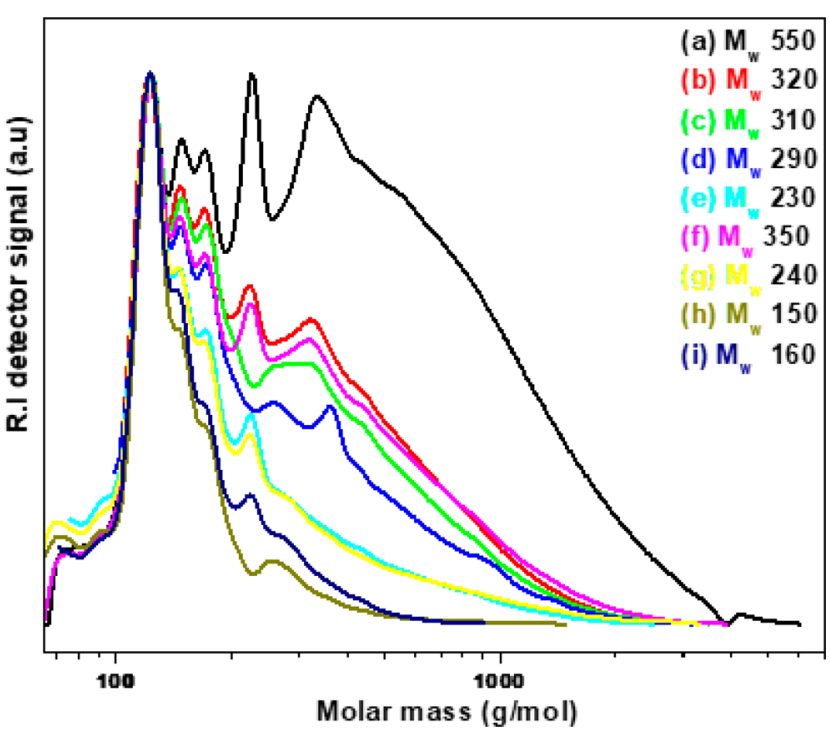

Figure 7. Gel permeation chromatograms of the lignin oils obtained using the $20 \mathrm{NiMoP} / \mathrm{AC}$ catalysts at different temperatures and reaction times: (a) $400{ }^{\circ} \mathrm{C}-0 \mathrm{~h}$, (b) $400{ }^{\circ} \mathrm{C}-2 \mathrm{~h}$, (c) $400{ }^{\circ} \mathrm{C}-4 \mathrm{~h},(\mathrm{~d})$ $400{ }^{\circ} \mathrm{C}-8 \mathrm{~h},(\mathrm{e}) 425{ }^{\circ} \mathrm{C}-4 \mathrm{~h},(\mathrm{f}) 450{ }^{\circ} \mathrm{C}-0 \mathrm{~h},(\mathrm{~g}) 450{ }^{\circ} \mathrm{C}-1 \mathrm{~h},(\mathrm{~h}) 450$ ${ }^{\circ} \mathrm{C}-4 \mathrm{~h}$, and (i) $500{ }^{\circ} \mathrm{C}-0 \mathrm{~h}$.

balance between depolymerization and repolymerization/ gasification determines the amount and molecular weight of the lignin oil. At the highest severity, very sharp peaks were observed without tailing, indicating the presence of large amounts of lower molecular weight components.

This was confirmed by GCXGC analysis (Table 5). The total monomer yield ranged from 20.5 to 39.9 wt \% on lignin intake, with slightly higher yields for the bimetallic $20 \mathrm{NiMoP} /$ AC catalysts. The highest value for $20 \mathrm{NiMoP} / \mathrm{AC}$ was found at low/intermediate severity, $400{ }^{\circ} \mathrm{C}$, and $4 \mathrm{~h}$ batch time. In combination with an oil yield of 64 wt $\%$ at these conditions, the lignin oil contains 62 wt \% of monomers, in line with the GPC data.

This maximum oil yield and amount of monomers for the $20 \mathrm{NiMoP} / \mathrm{AC}$ catalyst was found at the lowest temperature within the range of temperatures selected, and it is possible that better resuslts are attainable at lower temperatures. As such, a separate experiment was carried out with $20 \mathrm{NiMoP} /$ $\mathrm{AC}$ at $350^{\circ} \mathrm{C}$ and a $4 \mathrm{~h}$ bath time. In this case, the oil yield was $61.7 \mathrm{wt} \%$ and the total monomer yield was $20.5 \mathrm{wt} \%$ (GC $\times \mathrm{GC})$. In particular, the monomer yield is a factor of 2 lower than at $400{ }^{\circ} \mathrm{C}$, implying that the latter is indeed better than $350{ }^{\circ} \mathrm{C}$ when considering catalyst performance.

Effect of Catalyst Loading. The effect of catalyst loading (5 and $10 \mathrm{wt} \%$ ) on lignin oil yield and composition was studied at 400 and $450{ }^{\circ} \mathrm{C}$ using the $20 \mathrm{NiMoP} / \mathrm{AC}$ catalyst, and the results are given in Table 6 . The mass balances closures are good and in the range of $94-100 \%$. For the reactions performed at $400{ }^{\circ} \mathrm{C}$, the lignin oil yield increased from $67.2 \%$ to $70.6 \%$ upon increasing the catalyst loading from 5 to $10 \mathrm{wt} \%$. Char formation is reduced considerably, and actually no char is observed at the highest catalyst loading. As such, this implies that the repolymerization reactions leading ultimately to char are likely noncatalytic and thus thermal in nature, while the depolymerization reactions are metal catalyzed. Performance at $450{ }^{\circ} \mathrm{C}$ is worse, and more char and less oil are observed.

The lignin oils were further characterized by GPC, and the results are shown in Figure 8. Higher catalyst loadings at both temperatures lead to a reduction in the molecular weight of the lignin oils, indicative of a catalytic effect on the depolymerization reactions.

The volatility of the product oil obtained at $400{ }^{\circ} \mathrm{C}, 100 \mathrm{bar}$, and 10 wt \% catalyst loading was determined using TGA, and the results are given in Figure S8 (Supporting Information). It shows that more than $80 \%$ of the sample weight is lost when increasing the temperature from room temperature to $350{ }^{\circ} \mathrm{C}$, illustrating indeed that the amount of low molecular weight

Table 5. Monomer Yield (wt \% on lignin) and Component Class Distribution for the Lignin Oils Obtained Using the Phosphided Mono- and Bimetallic Mo-Based Catalysts ${ }^{a}$

\begin{tabular}{|c|c|c|c|c|c|c|c|}
\hline catalyst & temp. $\left({ }^{\circ} \mathrm{C}\right)$ & time $(\mathrm{h})$ & total monomer yield $(\%)^{b}$ & alkylphenolics $(\%)^{b}$ & $\operatorname{aromatics}(\%)^{b}$ & cyclic + linear alkanes $(\%)^{b}$ & $\operatorname{GPC}\left(M_{w}\right)$ \\
\hline 20NiMoP/AC & 350 & 4 & 20.5 & 11.4 & 2.7 & 5.2 & 860 \\
\hline \multirow[t]{4}{*}{$15 \mathrm{MoP} / \mathrm{AC}$} & \multirow[t]{4}{*}{400} & 0 & 20.5 & 13.5 & 2.2 & 2.1 & 550 \\
\hline & & 2 & 36.3 & 21.8 & 6.0 & 6.6 & 350 \\
\hline & & 4 & 38.7 & 22.4 & 8.0 & 7.4 & 300 \\
\hline & & 8 & 39.3 & 20.5 & 9.1 & 8.3 & 280 \\
\hline \multirow[t]{4}{*}{ 20NiMoP/AC } & \multirow[t]{4}{*}{400} & 0 & 24.5 & 14.1 & 2.4 & 2.6 & 550 \\
\hline & & 2 & 38.5 & 22.5 & 6.6 & 7.8 & 320 \\
\hline & & 4 & 39.9 & 22.5 & 7.6 & 8.0 & 310 \\
\hline & & 8 & 39.5 & 21.0 & 9.1 & 8.3 & 290 \\
\hline $20 \mathrm{MoP} / \mathrm{AC}$ & 425 & 4 & 39.6 & 19.0 & 10.4 & 7.2 & 220 \\
\hline 20NiMoP/AC & 425 & 4 & 38.9 & 22.2 & 10.1 & 6.1 & 230 \\
\hline \multirow[t]{3}{*}{$15 \mathrm{MoP} / \mathrm{AC}$} & \multirow[t]{3}{*}{450} & 0 & 31.2 & 21.3 & 4.3 & 2.9 & 300 \\
\hline & & 1 & 38.2 & 24.2 & 9.2 & 2.9 & 220 \\
\hline & & 4 & 32.9 & 16.6 & 11.6 & 3.4 & 170 \\
\hline \multirow[t]{3}{*}{ 20NiMoP/AC } & \multirow[t]{3}{*}{450} & 0 & 34.8 & 22.6 & 4.9 & 3.7 & 350 \\
\hline & & 1 & 39.2 & 22.9 & 8.9 & 4.9 & 240 \\
\hline & & 4 & 37.7 & 20.4 & 11.2 & 3.4 & 150 \\
\hline $15 \mathrm{MoP} / \mathrm{AC}$ & 500 & 0 & 33.0 & 20.4 & 8.1 & 3.2 & 150 \\
\hline $20 \mathrm{NiMoP} / \mathrm{AC}$ & 500 & 0 & 36.6 & 22.6 & 8.9 & 3.4 & 160 \\
\hline
\end{tabular}

${ }^{a}$ Reaction conditions: Kraft lignin, $15 \mathrm{~g}$; catalyst, $0.75 \mathrm{~g}$; hydrogen pressure of $100 \mathrm{bar}$ at RT; $1200 \mathrm{rpm} .{ }^{b}$ Percent is on weight basis of lignin intake. 
Table 6. Effect of Catalyst Loading on Lignin Oil Yield ${ }^{a}$

\begin{tabular}{|c|c|c|c|c|c|c|c|}
\hline catalyst loading (wt \% on lignin) & temp. $\left({ }^{\circ} \mathrm{C}\right)$ & time $(\mathrm{h})$ & oil yield $(\%)^{b}$ & gas phase $(\%)^{b}$ & water $(\%)^{b}$ & solids $(\%)^{b}$ & mass balance $(\%)^{b}$ \\
\hline 5 & $400^{a}$ & 2 & 67.2 & 8.6 & 19.7 & 4.0 & 99 \\
\hline 10 & $400^{a}$ & 2 & 70.6 & 9.4 & 20.7 & & 100 \\
\hline 5 & $450^{b}$ & 1 & 52.1 & 11.8 & 22.4 & 11.5 & 98 \\
\hline 10 & $450^{b}$ & 1 & 49.5 & 11.7 & 22.0 & 10.8 & 94 \\
\hline
\end{tabular}

${ }^{a}$ Reaction conditions: Kraft lignin, $15 \mathrm{~g}$; hydrogen pressure of 100 bar at RT; 1200 rpm. ${ }^{b}$ Percent is on weight basis of lignin intake.

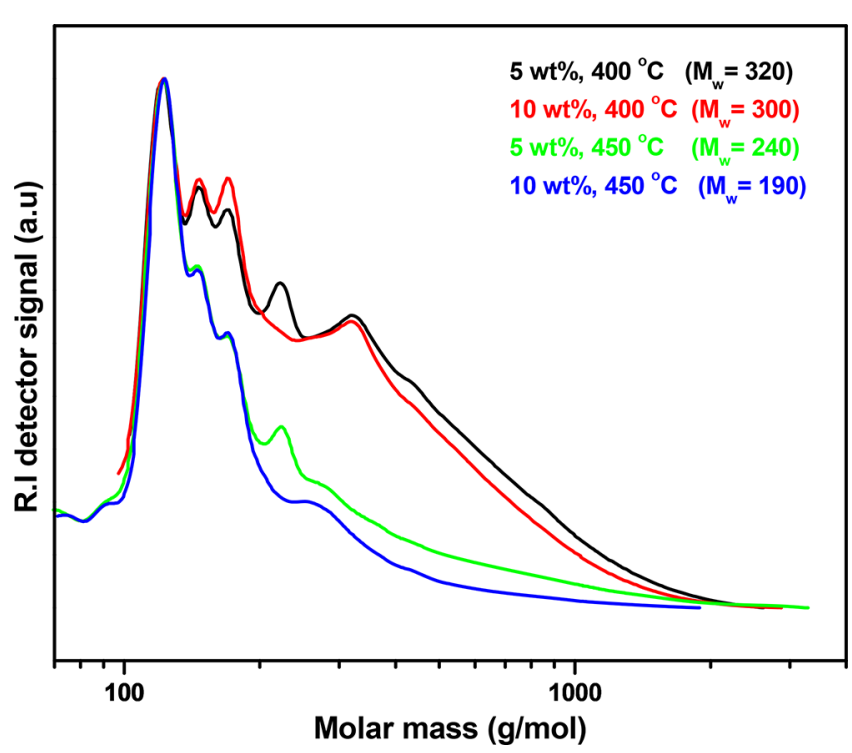

Figure 8. Effect of catalyst (20NiMoP/AC) loading on lignin oil average molecular weights.

compounds is high in the sample, in line with GPC and GCXGC data.

The monomer yield and the amounts of alkylphenolics, aromatics, and alkanes in the lignin oil, as determined by GC $\times$ GC analysis, are given in Figure 9. For reactions performed at $400{ }^{\circ} \mathrm{C}$, an increase in catalyst loading from 5 to $10 \mathrm{wt} \%$ leads to a higher monomers yield from $38.5 \%$ to

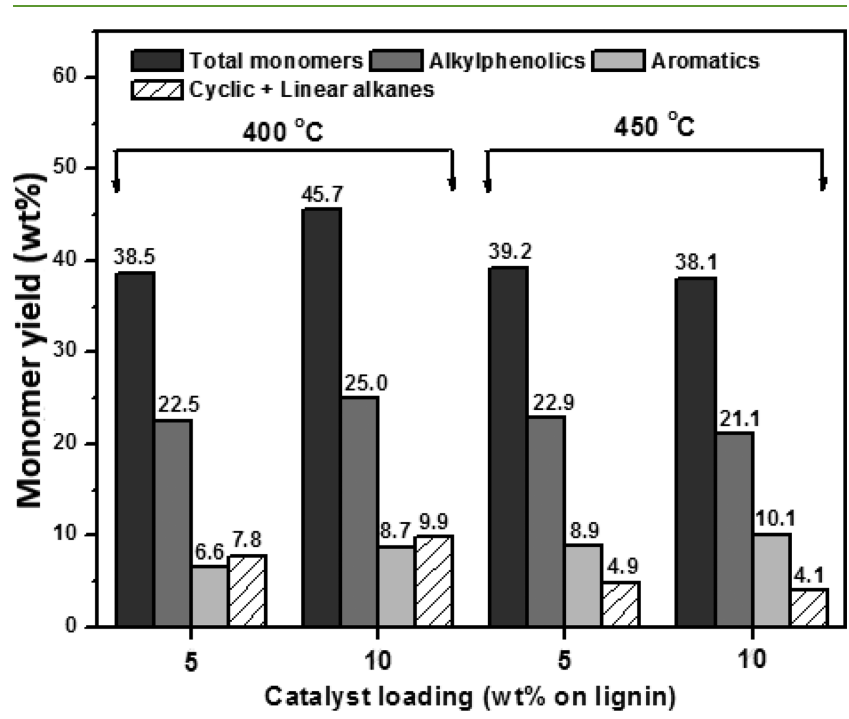

Figure 9. Effect of catalyst loading (20NiMoP/AC) and temperature on the monomer yield (wt \% on lignin) and amounts of important product classes (wt \% on lignin).
$45.7 \%$, the highest value obtained in this study. In this case, the alkylphenolics yield is $25 \mathrm{wt} \%$ on lignin.

Reaction Network. On the basis of the product yields and composition of the lignin oil (elemental analysis, GPC, GC$\mathrm{MS}$, GCXGC, and ${ }^{13} \mathrm{C} \mathrm{NMR}$ ) discussed in the previous sections and literature data, a reaction network is proposed for the hydrotreatment of Kraft lignin using metal phosphide catalysts and hydrogen (Scheme 1). It involves a number of serial and parallel reactions occurring in the liquid and gas phase. The desired reactions to low molecular weight alkylphenolics and aromatics involves thermal and catalytic depolymerization (hydrocracking) of the Kraft lignin by cleavage of linkages. The most reactive linkages are the ether linkages, though these are not highly abundant in Kraft lignin. Catalyst promotes depolymerization reactions, though reactions in the absence of a catalyst also give (limited) amounts of lignin oils, indicating that thermal depolymerization reactions also play a role (vide supra). The oligomeric fragments can either be further depolymerized to low molecular weight compounds in the form of alkylphenolics or repolymerize (also together with already formed low molecular weight compounds) to higher condensed structures, ultimately leading to char. The latter pathway is likely a thermal reaction and thus can be suppressed by the use of very active catalysts that reduce the amounts of reactive intermediates by catalyzing subsequent conversions. The intermediate low molecular weight alkylphenolics are not inert under reaction conditions and may be further hydrodeoxygenated to aromatics and alkanes, as is evident from the GCXGC results. Two possible pathways may be distinguished: (i) hydrodeoxygenation of alkylphenolics to aromatics and (ii) hydrogenation of the aromatic rings of the alkylphenolics followed by hydrodeoxygenation to form alkanes. The latter is undesirable as alkanes are less valuable than aromatics and typically only have fuel value. In addition, methoxy removal by hydrogenolysis reactions may also occur, as shown by model component studies, ${ }^{58,59}$ leading to the formation of methanol. The latter is likely not inert under the prevailing reaction conditions and may be converted to gas-phase components. ${ }^{60,61}$

When using the metal phosphide catalysts and particularly $20 \mathrm{NiMoP} / \mathrm{AC}$ at optimized conditions, high yields of alkylphenolics are obtained, with smaller amounts of aromatics, low amounts of overhydrogenated alkanes, and essentially no char. This means that the catalysts are very reactive at reported optimized conditions and promote hydrocracking reactions as well as methoxy removal reactions while being less reactive for hydrodeoxygention of alkylphenolics, leading to aromatics and hydrogenation reactions of the $\mathrm{C}-\mathrm{C}$ bonds in the aromatic rings to give alkanes.

Comparison of Catalytic Performance of the 20NiMoP/AC with Literature Data. The monomer yield for the best catalyst in this study (20NiMoP/AC) was compared with the data provided in the literature regarding the catalytic hydrotreatment of various lignins in the absence 
Scheme 1. Proposed Reaction Network for the Hydrotreatment of Kraft Lignin Using the Metal Phosphide Catalysts

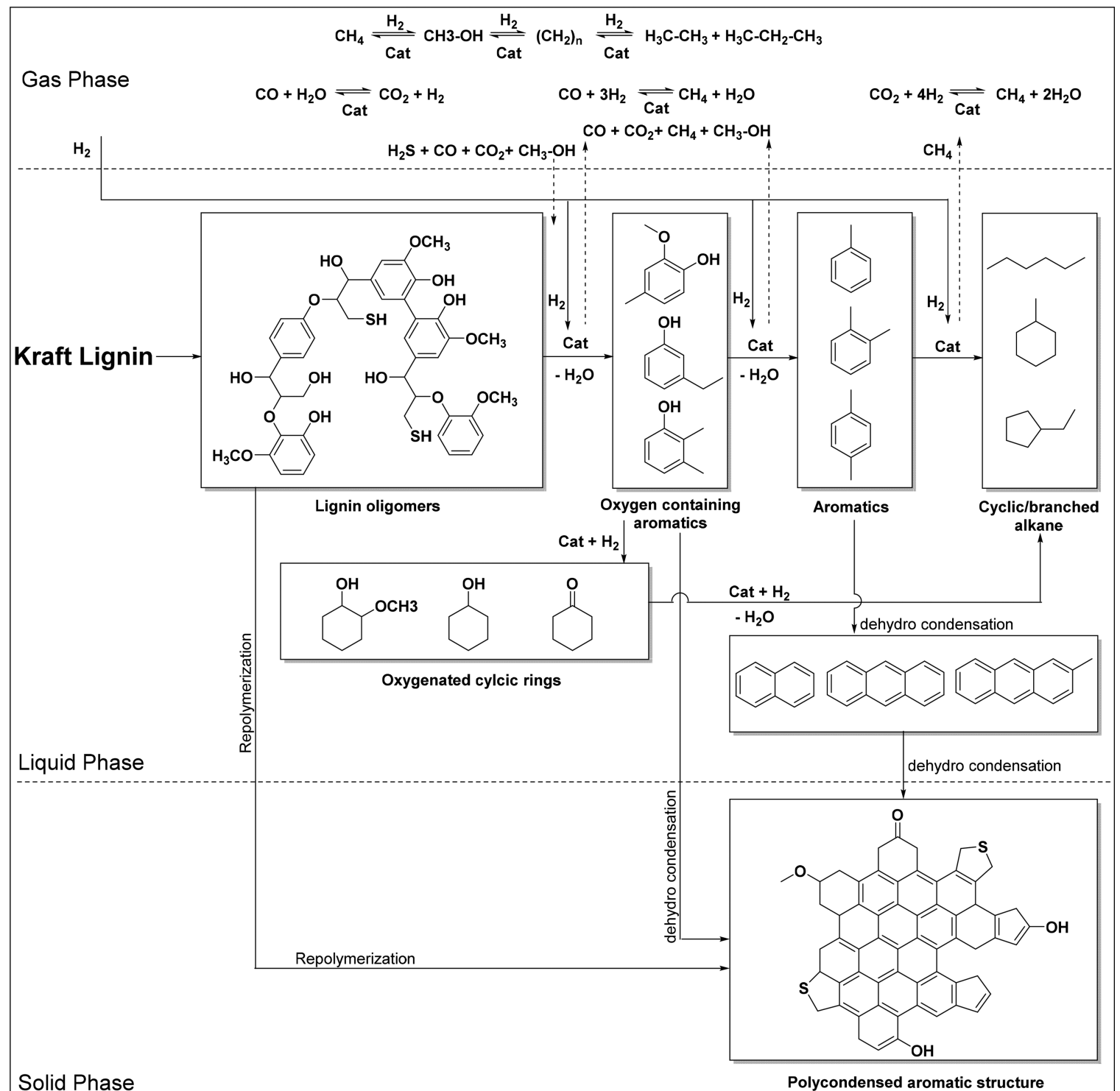

of an external solvent, and the results are given in Figure 10 and Table 1. When considering sulfur-containing lignins like Kraft lignin, the phosphided NiMo catalyst reported here performs best among the catalyst reported in the literature, and $45.7 \mathrm{wt} \%$ of monomers on lignin intake was obtained $\left(400^{\circ} \mathrm{C}\right.$, $2 \mathrm{~h}$ batch time, and $10 \mathrm{wt} \%$ of catalyst loading). Interestingly, performance is better than reported for sulfided NiMo catalysts on various supports, indicating the potential of phosphide catalyst for the catalytic hydrotreatment of (sulfur-containing) lignins. Monomer yield is lower than found for sulfur-free pyrolytic lignins, which is not surprising as this class of lignins has a considerably lower molecular weight than typical Kraft lignins.

\section{CONCLUSIONS}

A series of mono- and bimetallic Ni, Mo, and $\mathrm{W}$ phosphides supported on activated carbon was tested for the solvent-free catalytic hydrotreatment of Kraft lignin. Catalytic experiments showed that the Mo-containing phosphide catalysts exhibit better performance in terms of oil, char, and monomer yield compared to $\mathrm{W}$-containing metal phosphides. The effect of process conditions on catalytic performance of the Mocontaining mono- and bimetallic catalysts was investigated (400-500 ${ }^{\circ} \mathrm{C}$, batch times between 0 and $8 \mathrm{~h}$, catalyst loadings of 5 and 10 wt \%). The optimized reaction conditions for the $20 \mathrm{NiMoP} / \mathrm{AC}$ catalyst to obtain high monomer yields were determined to be $400{ }^{\circ} \mathrm{C}, 2 \mathrm{~h}$ batch time, and $10 \mathrm{wt} \%$ of catalyst loading. At these conditions, the monomer yield was $45.7 \%$ on lignin intake, which is significantly higher than values reported in the literature for the catalytic hydrotreatment of Kraft lignin without the use of an external solvent, showing the potential of this class of metal phosphides for the hydrotreatment of sulfur-rich lignins. The composition of the lignin oils was determined by GPC, GC-MS, GC $\times$ GC, and ${ }^{13} \mathrm{C}$ NMR and shown to consist of low molecular weight components as well as lignin oligomers (GPC). GC $\times \mathrm{GC}$ analysis shows that the most abundant monomers are alkylphenolics, with yields up to $25 \mathrm{wt} \%$ on lignin. To the best of our knowledge, we are the first to demonstrate that bimetallic NiMo phosphide-based catalysts are suitable for the hydrotreatment of Kraft lignin without the need for an external solvent. The main advantage compared to conventional sulfided NiMo catalysts on alumina 


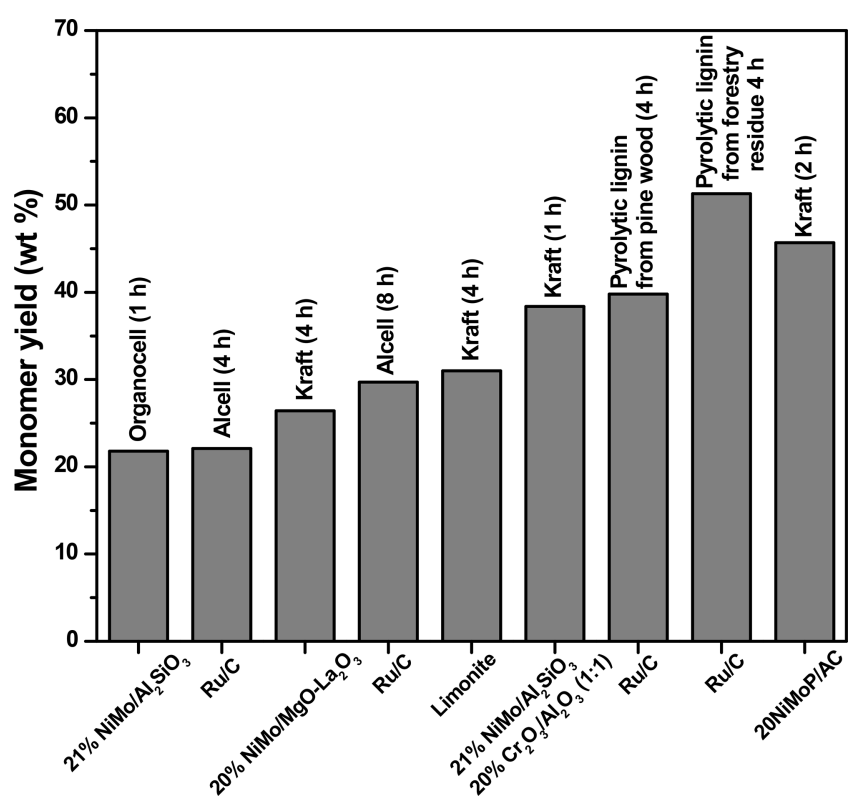

Figure 10. Overview of monomer yields for the solvent-free catalytic hydrotreatment of lignins (literature references to individual entries are given in Table 1; last column is the best result from this study).

supports is that the need of a sulfiding agent for good catalyst performance is not required.

\section{ASSOCIATED CONTENT}

\section{S Supporting Information}

The Supporting Information is available free of charge on the ACS Publications website at DOI: 10.1021/acssuschemeng.8b04411.

Visual appearance of a liquid product, catalyst characterization details (XRD, $\mathrm{N}_{2}$ physisorption, TEM), GC (GC-MS, GC $\times \mathrm{GC}$ ), GPC and TGA data of product oils, tables with mass balances including hydrogen consumption, gas-phase composition, model analysis data (coefficients and ANOVA), details about quantification of $\mathrm{GC} \times \mathrm{GC}$ chromatograms (PDF)

\section{AUTHOR INFORMATION}

\section{Corresponding Author}

*E-mail: h.j.heeres@rug.nl.

\section{ORCID $\odot$}

Hero Jan Heeres: 0000-0002-1249-543X

\section{Notes}

The authors declare no competing financial interest.

\section{ACKNOWLEDGMENTS}

This research has been performed within the framework of the CatchBio program, project 053.70.732. The authors gratefully acknowledge the financial support of the Smart Mix program of the Ministry of Economic Affairs and The Netherlands Ministry of Education, Culture and Science. We also thank Anne Appeldoorn, Erwin Wilbers, Marcel de Vries, Hans van der Velde, Leon Rohrbach, and Jan Henk Marsman for technical and analytical support.

\section{REFERENCES}

(1) Huber, G. W.; Iborra, S.; Corma, A. Synthesis of Transportation Fuels from Biomass: Chemistry, Catalysts, and Engineering. Chem. Rev. 2006, 106 (9), 4044-4098.

(2) Melero, J. A.; Iglesias, J.; Garcia, A. Biomass as renewable feedstock in standard refinery units. Feasibility, opportunities and challenges. Energy Environ. Sci. 2012, 5, 7393-7420.

(3) Gallezot, P. Conversion of biomass to selected chemical products. Chem. Soc. Rev. 2012, 41 (4), 1538-1558.

(4) Tuck, C. O.; Perez, E.; Horvath, I. T.; Sheldon, R. A.; Poliakoff, M. Valorization of Biomass: Deriving More Value from Waste. Science 2012, 337, 695-699.

(5) Hon, D. N. S.; Shiraishi, N. Wood and Cellulosic Chemistry; Marcel Dekker: New York and Basel, 1991.

(6) Sjostrom, E. Wood chemistry, fundamentals and applications, 2nd ed.; Academic Press: San Diego, 1992.

(7) Fengel, D.; Wegener, G. Wood: Chemistry, Ultrastructure, Reactions; Walter de Gruyter: New York, 1984.

(8) Li, C.; Zhao, X.; Wang, A.; Huber, G. W.; Zhang, T. Catalytic Transformation of Lignin for the Production of Chemicals and Fuels. Chem. Rev. 2015, 115 (21), 11559-11624.

(9) Clark, J. H.; Luque, R.; Matharu, A. S. Green chemistry, biofuels, and biorefinery. Annu. Rev. Chem. Biomol. Eng. 2012, 3, 183-207.

(10) Watkins, D.; Nuruddin, Md.; Hosur, M.; Tcherbi-Narteh, A. T.; Jeelani, S. Extraction and characterization of lignin from different biomass resources. J. Mater. Res. Technol. 2015, 4 (1), 26-32.

(11) Sun, X. F.; Cang, R.; Fowler, P.; Baird, M. S. J. Agric. Extraction and Characterization of Original Lignin and Hemicelluloses from Wheat Straw. J. Agric. Food Chem. 2005, 53 (4), 860-870.

(12) Brandt, A.; Gräsvik, J.; Hallett, J. P.; Welton, T. Deconstruction of lignocellulosic biomass with ionic liquids. Green Chem. 2013, 15, 550-583.

(13) Laurichesse, S.; Averous, L. Chemical modification of lignins: Towards biobased polymers. Prog. Polym. Sci. 2014, 39, 1266-1290.

(14) Gosselink, R. J. A.; de Jong, E.; Guran, B.; Abacherli, A. Coordination network for lignin standardisation, production and applications adapted to market requirements (EUROLIGNIN). Ind. Crops Prod. 2004, 20, 121-129.

(15) Kleinert, M.; Barth, T. Phenols from Lignin. Chem. Eng. Technol. 2008, 31 (5), 736-745.

(16) Thring, R. W.; Katikaneni, S. P. R.; Bakhshi, N. N. The production of gasoline range hydrocarbons from Alcell $^{\circledR}$ lignin using HZSM-5 catalyst. Fuel Process. Technol. 2000, 62, 17-30.

(17) Gellerstedt, G.; Li, J.; Eide, I.; Kleinert, M.; Barth, T. Chemical Structures Present in Biofuel Obtained from Lignin. Energy Fuels 2008, 22 (6), 4240-4244.

(18) Rahimi, A.; Ulbrich, A.; Coon, J. J.; Stahl, S. S. Formic-acidinduced depolymerization of oxidized lignin to aromatics. Nature 2014, 515 (7526), 249-252.

(19) Zhu, H.; Chen, Y.; Qin, T.; Wang, L.; Tang, Y.; Sun, Y.; Wan, P. Lignin depolymerization via an integrated approach of anode oxidation and electro-generated $\mathrm{H}_{2} \mathrm{O}_{2}$ oxidation. RSC Adv. 2014, 4, $6232-6238$

(20) Chatel, G.; Rogers, R. D. Review: Oxidation of Lignin Using Ionic Liquids-An Innovative Strategy To Produce Renewable Chemicals. ACS Sustainable Chem. Eng. 2014, 2, 322-339.

(21) Zakzeski, J.; Bruijnincx, P. C. A.; Jongerius, A. L.; Weckhuysen, B. M. The Catalytic Valorization of Lignin for the Production of Renewable Chemicals. Chem. Rev. 2010, 110 (6), 3552-3599.

(22) Singh, S. K.; Ekhe, J. D. Cu-Mo doped zeolite ZSM-5 catalyzed conversion of lignin to alkyl phenols with high selectivity. Catal. Sci. Technol. 2015, 5, 2117-2124.

(23) Deepa, A. K.; Dhepe, P. L. Lignin Depolymerization into Aromatic Monomers over Solid Acid Catalysts. ACS Catal. 2015, 5 (1), 365-379.

(24) Parsell, T.; Yohe, S.; Degenstein, J.; Jarrell, T.; Klein, I.; Gencer, E.; Hewetson, B.; Hurt, M.; Kim, J. I.; Choudhari, H.; Saha, B.; Meilan, R.; Mosier, N.; Ribeiro, F.; Delgass, W. N.; Chapple, C.; Kenttamaa, H. I.; Agrawal, R.; Omar, M. M. A. A synergistic 
biorefinery based on catalytic conversion of lignin prior to cellulose starting from lignocellulosic biomass. Green Chem. 2015, 17, 14921499.

(25) Olcese, R. N.; Lardier, G.; Bettahar, M.; Ghanbaja, J.; Fontana, S.; Carre, V.; Aubriet, F.; Petitjean, D.; Dufour, A. Aromatic Chemicals by Iron-Catalyzed Hydrotreatment of Lignin Pyrolysis Vapor. ChemSusChem 2013, 6, 1490-1499.

(26) Li, X.; Su, L.; Wang, Y.; Yu, Y.; Wang, C.; Li, X.; Wang, Z. Catalytic fast pyrolysis of Kraft lignin with HZSM-5 zeolite for producing aromatic hydrocarbons. Front. Environ. Sci. Eng. 2012, 6 (3), 295-303.

(27) Lazaridis, P. A.; Fotopoulos, A. P.; Karakoulia, S. A.; Triantafyllidis, K. S. Catalytic Fast Pyrolysis of Kraft Lignin With Conventional, Mesoporous and Nanosized ZSM-5 Zeolite for the Production of Alkyl-Phenols and Aromatics. Front. Chem. 2018, 6, 295.

(28) Xu, C.; Arancon, R. A. D.; Labidi, J.; Luque, R. Lignin depolymerisation strategies: towards valuable chemicals and fuels. Chem. Soc. Rev. 2014, 43 (22), 7485-7500.

(29) Jongerius, A. L.; Bruijnincx, P. C. A.; Weckhuysen, B. M. Liquid-phase reforming and hydrodeoxygenation as a two-step route to aromatics from lignin. Green Chem. 2013, 15, 3049-3056.

(30) Azadi, P.; Inderwildi, O. R.; Farnood, R.; King, D. A. Liquid fuels, hydrogen and chemicals from lignin: A critical review. Renewable Sustainable Energy Rev. 2013, 21, 506-523.

(31) Barta, K.; Ford, P. C. Catalytic Conversion of Nonfood Woody Biomass Solids to Organic Liquids. Acc. Chem. Res. 2014, 47, 15031512.

(32) Ma, X.; Ma, R.; Hao, W.; Chen, M.; Yan, F.; Cui, K.; Tian, Y.; Li, Y. Common Pathways in Ethanolysis of Kraft Lignin to Platform Chemicals over Molybdenum-Based Catalysts. ACS Catal. 2015, 5, 4803-4813.

(33) Ma, R.; Hao, W.; Ma, X.; Tian, Y.; Li, Y. Catalytic Ethanolysis of Kraft Lignin into High-Value Small-Molecular Chemicals over a Nanostructured $\alpha$-Molybdenum Carbide Catalyst. Angew. Chem., Int. Ed. 2014, 53 (28), 7310-7315.

(34) Huang, X.; Korányi, T. I.; Boot, M. D.; Hensen, E. J. M. Catalytic Depolymerization of Lignin in Supercritical Ethanol. ChemSusChem 2014, 7, 2276-2288.

(35) Löfstedt, J.; Dahlstrand, C.; Orebom, A.; Meuzelaar, G.; Sawadjoon, S.; Galkin, M. V.; Agback, P.; Wimby, M.; Corresa, E.; Mathieu, Y.; Sauvanaud, L.; Eriksson, S.; Corma, A.; Samec, J. S. M. Green Diesel from Kraft Lignin in Three Steps. ChemSusChem 2016, 9, 1392-1396.

(36) Pandey, M. P.; Kim, C. S. Lignin Depolymerization and Conversion: A Review of Thermochemical Methods. Chem. Eng. Technol. 2011, 34, 29-41.

(37) Mohan, D.; Pittman, C. U.; Steele, P. H. Pyrolysis of Wood/ Biomass for Bio-oil: A Critical Review. Energy Fuels 2006, 20, 848889.

(38) Roberts, V.; Stein, V.; Reiner, T.; Lemonidou, A.; Li, X.; Lercher, J. A Towards quantitative catalytic lignin depolymerisation. Chem. - Eur. J. 2011, 17 (21), 5939-5948.

(39) Onwudili, J. A.; Williams, P. T. Catalytic depolymerization of alkali lignin in subcritical water: influence of formic acid and $\mathrm{Pd} / \mathrm{C}$ catalyst on the yields of liquid monomeric aromatic products. Green Chem. 2014, 16, 4740-4748.

(40) Narani, A.; Chowdari, R. K.; Cannilla, C.; Bonura, G.; Frusteri, F.; Heeres, H. J.; Barta, K. Efficient catalytic hydrotreatment of Kraft lignin to alkylphenolics using supported NiW and NiMo catalysts in supercritical methanol. Green Chem. 2015, 17, 5046-5057.

(41) Kloekhorst, A.; Shen, Y.; Yie, Y.; Fang, M.; Heeres, H. J. Catalytic hydrodeoxygenation and hydrocracking of Alcell ${ }^{\circledR}$ lignin in alcohol/formic acid mixtures using a $\mathrm{Ru} / \mathrm{C}$ catalyst. Biomass Bioenergy 2015, 80, 147-161.

(42) Meier, D.; Ante, R.; Faix, O. Catalytic hydropyrolysis of lignin: Influence of reaction conditions on the formation and composition of liquid products. Bioresour. Technol. 1992, 40, 171-177.
(43) Oasmaa, A.; Alen, R.; Meier, D. Catalytic hydrotreatment of some technical lignins. Bioresour. Technol. 1993, 45 (3), 189-194.

(44) Kloekhorst, A.; Wildschut, J.; Heeres, H. J. Catalytic hydrotreatment of pyrolytic lignins to give alkylphenolics and aromatics using a supported $\mathrm{Ru}$ catalyst. Catal. Sci. Technol. 2014, 4, 2367-2377.

(45) Kloekhorst, A.; Heeres, H. J. Catalytic Hydrotreatment of Alcell Lignin Using Supported $\mathrm{Ru}, \mathrm{Pd}$, and Cu Catalysts. ACS Sustainable Chem. Eng. 2015, 3, 1905-1914.

(46) Kumar, Ch. R.; Anand, N.; Kloekhorst, A.; Cannilla, C.; Bonura, G.; Frusteri, F.; Barta, K.; Heeres, H. J. Solvent free depolymerization of Kraft lignin to alkyl-phenolics using supported NiMo and CoMo catalysts. Green Chem. 2015, 17, 4921-4930.

(47) Agarwal, S.; Chowdari, R. K.; Hita, I.; Heeres, H. J. Experimental Studies on the Hydrotreatment of Kraft Lignin to Aromatics and Alkylphenolics Using Economically Viable Fe-Based Catalysts. ACS Sustainable Chem. Eng. 2017, 5 (3), 2668-2678.

(48) de Wild, P. J.; Huijgen, W. J. J.; Kloekhorst, A.; Chowdari, R. K.; Heeres, H. J. Biobased alkylphenols from lignins via a two-step pyrolysis - Hydrodeoxygenation approach. Bioresour. Technol. 2017, 229, 160-168.

(49) Wu, S. K.; Lai, P. C.; Lin, Y. C.; Wan, H. P.; Lee, H. T.; Chang, Y. H. Atmospheric Hydrodeoxygenation of Guaiacol over Alumina-, Zirconia-, and Silica-Supported Nickel Phosphide Catalysts. ACS Sustainable Chem. Eng. 2013, 1 (3), 349-358.

(50) Zhao, H. Y.; Li, D.; Bui, P.; Oyama, S. T. Hydrodeoxygenation of guaiacol as model compound for pyrolysis oil on transition metal phosphide hydroprocessing catalysts. Appl. Catal., A 2011, 391 (1-2), 305-310.

(51) Ma, X. L.; Tian, Y.; Hao, W. Y.; Ma, R.; Li, Y. D. Production of phenols from catalytic conversionof lignin over a tungsten phosphide catalyst. Appl. Catal., A 2014, 481, 64-70.

(52) Li, C.; Zhao, X.; Wang, A.; Huber, G. W.; Zhang, T. Catalytic Transformation of Lignin for the Production of Chemicals and Fuels. Chem. Rev. 2015, 115 (21), 11559-11624.

(53) Bowker, R. H.; Ilic, B.; Carrillo, B. A.; Reynolds, M. A.; Murray, B. D.; Bussell, M. E. Carbazole hydrodenitrogenation over nickel phosphide and Ni-rich bimetallic phosphide catalysts. Appl. Catal., A 2014, 482, 221-230.

(54) Burns, A. W.; Gaudette, A. F.; Bussell, M. E. Hydrodesulfurization properties of cobalt-nickel phosphide catalysts: Nirich materials are highly active. J. Catal. 2008, 260 (2), 262-269.

(55) Constant, S.; Wienk, H. L. J.; Frissen, A. E.; Peinder, P.d.; Boelens, R.; van Es, D. S.; Grisel, R. J. H.; Weckhuysen, B. M.; Huijgen, W. J. J.; Gosselink, R. J. A.; Bruijnincx, P. C. A. New insights into the sructure and composition of technical lignins: a comparative characterisation study. Green Chem. 2016, 18 (9), 2651-2665.

(56) Yang, P.; Kobayashi, H.; Hara, K.; Fukuoka, A. Phase Change of Nickel Phosphide Catalysts in the Conversion of Cellulose into Sorbitol. ChemSusChem 2012, 5, 920-926.

(57) Yao, Z. W. Exploration on synthesis of activated carbon supported molybdenum carbide, nitride and phosphide via carbothermal reduction route. J. Alloys Compd. 2009, 475, L38-L41.

(58) Maki-Arvela, P.; Murzin, D. Y. Hydrodeoxygenation of LigninDerived Phenols: From Fundamental Studies towards Industrial Applications. Catalysts 2017, 7 (9), 265.

(59) Li, X.; Chen, G.; Liu, C.; Ma, W.; Yan, B.; Zhang, J. Hydrodeoxygenation of lignin-derived bio- oil using molecular sieves supported metal catalysts: A critical review. Renewable Sustainable Energy Rev. 2017, 71, 296-308.

(60) Gabriel, S.; Scurrell, M. S. The Conversion of Methanol into Higher Hydrocarbons Catalyzed by Gold. ChemCatChem 2016, 8 (19), 3118-3120.

(61) Ilias, S.; Bhan, A. Mechanism of the Catalytic Conversion of Methanol to Hydrocarbons. ACS Catal. 2013, 3, 18-31. 